
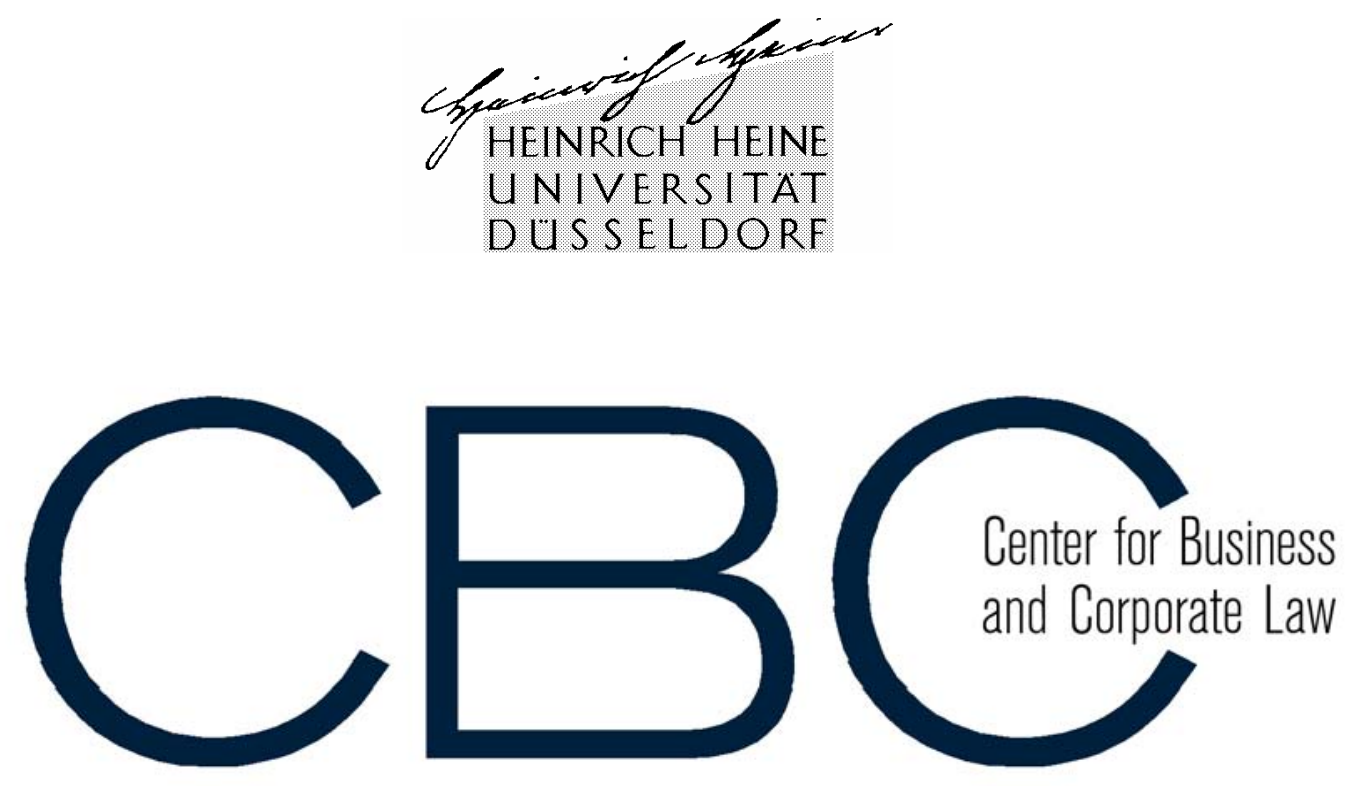

Heinrich-Heine-Universität Düsseldorf - Juristische Fakultät Arbeitspapiere des Instituts für Unternehmensrecht (IUR)

Heinrich-Heine-University Duesseldorf / Germany

- Faculty of Law -

Center for Business and Corporate Law Research Paper Series (CBC-RPS)

http://www.jura.uni-duesseldorf.de/institute/iur/ind_ger.html

Autor / Author (E-Mail): Dirk A. Zetzsche

E-Mail: $\quad$ zetzsche@uni-duesseldorf.de

Titel / Title: $\quad$ An Ethical Theory of Corporate Governance History

CBC Nummer / Number: 0006 (02/2007)

SSRN Nummer / Number: $\quad$ http://ssrn.com/abstract=970909

Schlagworte / Keywords: Corporate Governance; history; corporate control; shareholder; stakeholder

JEL Classifications: $\quad$ B20, G32, G34, G38, K22, K33 


\title{
An Ethical Theory of Corporate Governance History
}

\author{
Dirk A. Zetzsche \\ Center of Business and Corporate Law (CBC) \\ Heinrich-Heine-University \\ Faculty of Law \\ Düsseldorf/Germany
}

February, 2007

- Dr. jur. (Heinrich Heine University, Duesseldorf / Germany), LL.M. (University of Toronto, Ont. / Canada), Faculty of Law at Heinrich Heinrich Heine University and President of Duesseldorf Law School (the graduate law department at HHU).

I am grateful to Bill Bratton, Rosemariè Eznak, Nils Goldschmidt, Kathleen Grandy, Ed Iacobucci, Charles Kahn, Tim Kleinevoss, Amir Licht, Kyrill Makoski, Larry Mitchell, Jose Manuel Moreira, Gioia Morasch, Ulrich Noack, Wolfgang Ockenfels, Uriel Procaccia, Anton Rauscher, Johannes Schneider, Constans Seyfarth, Mathias Siems, Chris Wright, Hartmut and Regina Zetzsche, as well as to the participants of the $3^{\text {rd }}$ SLOAN Retreat on Business in Society (George Washington University) and members of the Catholic Student Society, Duesseldorf/Germany.

My research was generously supported by the DFG - Deutsche Forschungsgemeinschaft (German Research Foundation), the SLOAN Foundation, and the Center for Business \& Corporate Law (CBC) at Heinrich Heine University. 


\begin{abstract}
:
The present Anglo-American system of corporate control is said to be a random result of market forces, the strong influence of which resulted from a weak state, and undefined principles in the state's economic policy until the 1930s. In contrast, in Continental Europe, strong states with a tendency to interfere with market forces were established. The events resulting in these two divergent systems must be analysed in order to understand what predominant factors catalyzed the development of the current corporate governance structures. Though values other than religious principles are likely to prevail today, this paper posits that religious foundations provide a sound explanation for the developmental path of corporate governance in Anglo-America and Continental Europe. Further, it assesses the impact of such an ethical theory of corporate governance history on contemporary convergence debate. In particular, it asserts that ethical restraints may explain path dependency, and that such an ethical path dependency is more likely in times of economic decline than in times of economic growth. Finally, it holds that, in homogeneous societies, ethics can in many respects substitute for good law.
\end{abstract}


Table of Contents

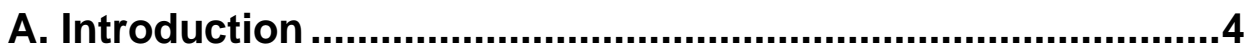

I. Common and Civil Law Jurisdictions .................................

II. Market- and Bank-Centered Economies ..............................9

III. Shareholder vs. Stakeholder Primacy..............................11

IV. Explicit and Implicit System of Corporate Control ..............15

C. The Roots of Contemporary Corporate Governance Systems - , An Ethical Theory ..............................................................18

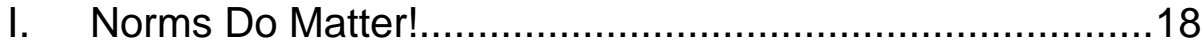

II. The Normative Pillars of Western Culture .........................21

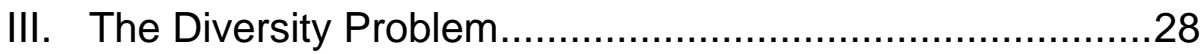

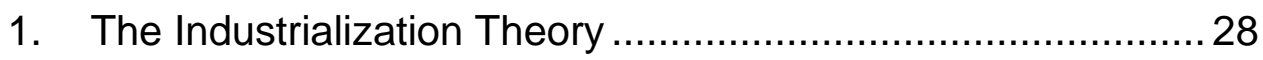

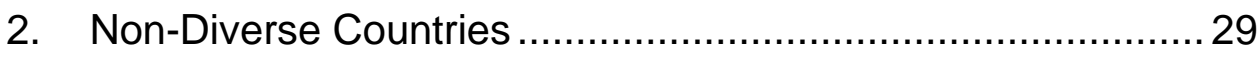

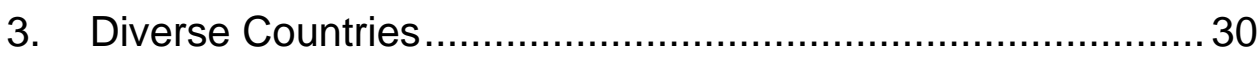

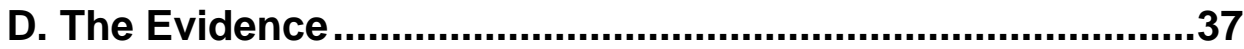

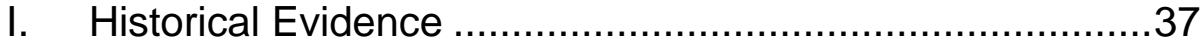

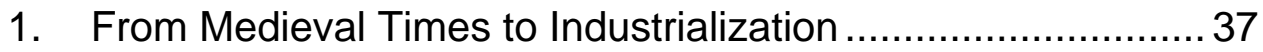

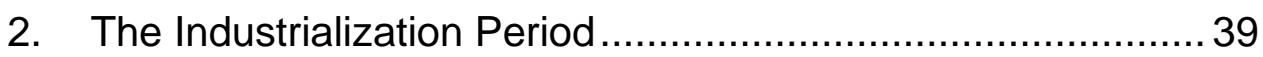

3. Continuation in $20^{\text {th }}$ Century Politics....................................... 45

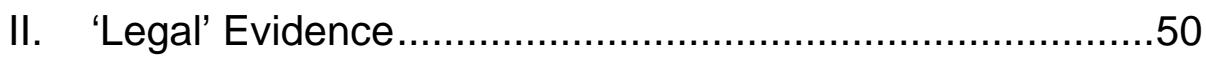

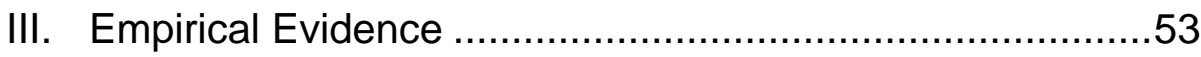

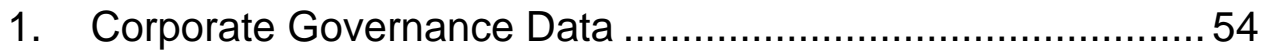

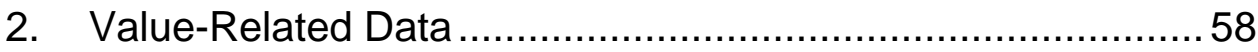

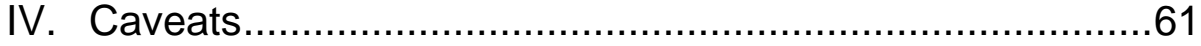

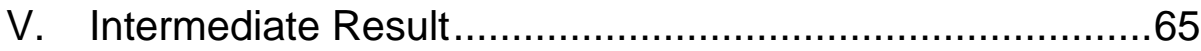

\section{E. Shareholder Value in the Present and Future:}

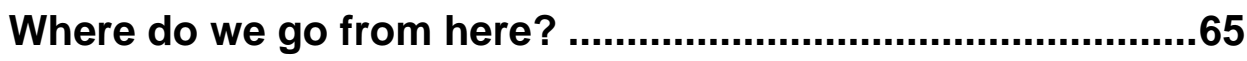

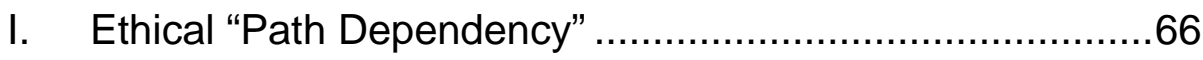

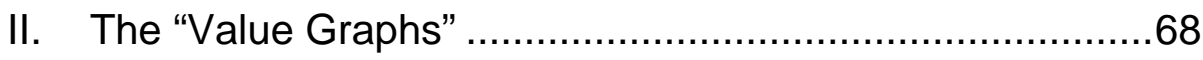

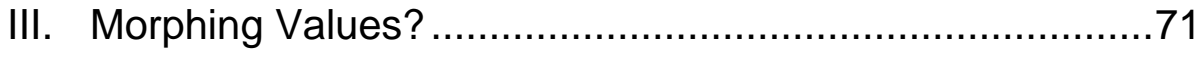

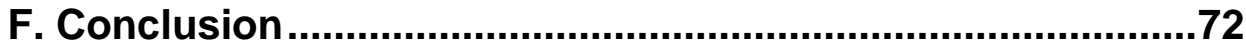




\section{A. Introduction}

The present Anglo-American system of corporate control is said to be a random result of market forces, the strong influence of which was the result of a weak state, and undefined principles in the state's economic policy until the 1930s. ${ }^{1}$ In contrast, in Continental Europe, strong states which tended to interfere with market forces were established. ${ }^{2}$ The events leading up to these two divergent systems must be analysed in order to determine the factors that catalyzed the development of the current corporate governance structures.

Though values other than religious principles are likely to prevail today, this paper posits that religious foundations provide a sound explanation for the developmental path of corporate governance in Anglo-America and Continental Europe. In addition, it assesses the impact of such an ethical theory of corporate governance history on the contemporary convergence debate.

This paper is structured as follows. Part B. provides an overview, as well as critique, of the traditional categories of corporate governance systems. In an attempt to overcome the weaknesses that other categorizations of contemporary corporate governance systems exhibit, part C. develops an ethical theory of corporate governance history. It maintains that the different developments can be attributed to the specific strains of Christendom that prevailed in Anglo-America and Western Europe during the age of industrialization. Specifically, the focus is on whether a country developed strong capital markets (which are the precondition for a system herein called an 'implicit system of corporate control'), or whether it developed explicit methods of corporate control. Naturally, some countries' societies are and have always been reasonably heterogeneous in terms of religion. With respect to religious diversity, this paper argues that the ethical

\footnotetext{
${ }^{1}$ John C. Coffee, Jr., The Rise of Dispersed Ownership: The Role of Law and the State in the Separation of Ownership and Control, 111 Yale L.J. 1, 24 et seq. (2001) [hereinafter The Rise]. Later, however, the American legislature interfered with a free development of banking structures, see Mark J. Roe, Strong Managers, Weak Owners: The Political Roots of AMERICAN CORPORATE FINANCE 26 (Princeton University Press 1994).

${ }^{2} I d$.
} 
strain which politically dominated in the age of industrialization became influential on all later corporate governance systems. Part D. presents historical, systemic, and empirical evidence for my thesis, and discusses alternative explanations for the phenomena understood as evidence in this paper. Part E. assesses the impact of my theory on present theories of corporate governance convergence, as well as the good law - bad law debate which is closely associated with the former. If, in fact, ethics do influence the efficiency of any particular corporate governance device, transferring the legal scheme of one successful corporate governance system to another is unlikely to yield the desired results. Unless societies become indifferent with respect to cultural values that are based on religion, the ethical theory suggests that the legal scheme needs to be adjusted to suit the specific ethical background of the corporate governance system to which it is being transferred. This phenomenon, coined as "ethical path dependency," supports the hypothesis that a “one size fits all” optimum cannot apply to all countries. Further, it might add to the existing explanations of why simply adopting a foreign legal model does not achieve the same results as the legal regime achieves in its country of origin. Finally, understanding the relationship between ethics and law helps us to better understand when ethics not law - matter most. 


\section{B. Traditional Categories of Corporate Governance Systems}

Two types of legal studies utilize the concept of corporate governance categories. Some comparative literature focuses on systemic issues, examining forces that generally influence tendencies toward convergence and persistence. Another field of comparative literature examines specific elements of corporate governance systems, such as the presence of different types of shareholders, the degree of capital market development, and the degree of minority shareholder protection in order to account for differences between American and European corporate governance systems. While every categorization requires a minimum degree of flexibility in order to remain adaptable to different circumstances, e.g. to more than a limited number of countries, or to transition periods, most of the categorizations that current scholarship provides can be criticized from a methodological perspective for exhibiting deficiencies with respect to their doctrinal and statutory bases.

This section discusses some of the most prominently argued misconceptions in drawing wedges between closely interrelated (both culturally and economically) economies. As Hayek suggested (in another context), grave consequences may follow from accepting "seemingly simple but false" categories. $^{3}$ Thus, the adjustment of three biases is particularly essential for the purposes of further discussion. These are (1) the distinction between common and civil law jurisdictions, ${ }^{4}$ (2) the distinction between market and bankdriven economies, ${ }^{5}$ and (3) Hansmann \& Kraakman's provocative assertion ${ }^{6}$ that

3 Friedrich Hayek, The Pretense of Knowledge in THE EsSENCE OF HAYEK 266, 272 (Nishijama \& Leube eds. 1984).

${ }^{4}$ Primarily established by Rafael La Porta, Florencio Lopez-De-Silanes, Andrei Shleifer, Corporate Ownership around the World 54 J. Fin. 471, 473 (1999) [hereinafter Corporate Ownership]; Rafael La Porta, Florencio Lopez-De-Silanes, Andrei Shleifer, Robert Vishny, Legal Determinants of External Finance 52 J. Fin. 1131 (1997); Law and Finance 106 J. Pol. Econ. 1113, 1116 (1998); Investor Protection and Corporate Governance 58 J. Fin. Econ. 3 (2000); reconsidered, e.g., by Coffee, The Rise, supra note 1, at 45, 60 et seq.

${ }^{5}$ For example, Bernard S. Black, The Legal and Institutional Preconditions for Strong Securities Markets 48 UCLA L.R. 781, 842 (2000-2001) [hereinafter The Legal and Institutional Preconditions]; Gustavo Visentini, Compatibility and Competition Between European and American Corporate Governance: Which Model of Capitalism? 23 Brook. J. Int'l L. 833, 846 et seq. (1997-1998); La Porta et al. Corporate Ownership, supra note 4, at 508. 
only the present American corporate world would be shareholder driven, while in France, the state would regularly intervene in corporate matters, and in Germany, labor interests would influence corporate decision making (at least) as much as would shareholder interests. Criticism is primarily helpful only if paired with better proposals. This is presented with the author's distinction between Explicit and Implicit Systems of corporate control.

\section{Common and Civil Law Jurisdictions}

Relying on a distinction between civil and common law countries raises three major concerns. First, in many cases it is unclear what qualifies each country for membership in a specific category. For example, Japan is usually considered to be a civil law country. While the roots of the Japanese legal system are German, and it is thus based on civil law, the categorization neglects the fact that Japanese law after the Second World War has been fundamentally reformed under strong influence from the American state law of Illinois. ${ }^{7}$ Second, a bright-line distinction between European common and civil law countries can be questioned from an historical perspective: The original "common law" was the "canon law" or "jus commune" that was applied in bishops' courts throughout the West. ${ }^{8}$ Why should then common law be so important for the developments of an "efficient" legal system in England, while it should not have been in Germany, where in the fourteenth and fifteenth centuries the church courts also had wide jurisdiction and played an extremely important role in shaping the legal system? ${ }^{9}$ Further, how do traditional cultural ties, or antagonism, which can be assumed to impact legal

\footnotetext{
${ }^{6}$ Henry Hansman \& Reinier Kraakman, The End of History for Corporate Law, (2001) 89 Georgetown L.J. 439, 443 et seq. [hereinafter The End].

${ }^{7}$ For Japan’s hybrid law background see Curtis Milhaupt, Creative Norm Destruction: The Evolution of Nonlegal Rules in Japanese Corporate Governance 149 U. Pa. L.R. 2083, 2123 Fn. 131 (2001); Mathias Siems, Die KonVERGENZ DER REChtSSYSTEME IM RECHT DER AKTIONÄre, 7, 23-4 [THE CONVERgenCe of Legal Systems IN THE LAW ON SHAREHOLDERS - A Study ON Comparative Corporate Governance in the Era of Globalisation] (Mohr Jus Privatum 2005) [hereinafter SIEMS, CONVERGENCE (2005)].

${ }^{8}$ Harold J. Berman, Law and Revolution II - The Impact of the Protestant Reformations on the Western Legal Tradition 35 (Harvard University Press 2003, Paperback 2006).

${ }^{9}$ Id.
} 
development as well, fit into the picture? ${ }^{10}$ For example, traditionally strong ties existed between the Netherlands, a civil law country, and England, a common law country. ${ }^{11}$ Third, law \& finance theorists disregard the differences between today's common law and the common law that was exercised by courts in medieval England (which, according to La Porta et al., should have been the period that made the difference for legal development to this day ). Firstly, the Stuart Kings removed parts of the traditional law when it conflicted with the King's power to charter corporations. ${ }^{12}$ Moreover, the doctrine of precedent, which is the hallmark of common law, received its modern meaning after the Glorious Revolution in $1689 .{ }^{13}$ In light of these facts, it is interesting to note that comparative studies as to the underlying legal assumptions of court activity in England and Germany show that court practice, at least in the last centuries, did not differ significantly. ${ }^{14}$ Thus, as to how the "legal family" should matter remains unclear.

10 Amir N. Licht, Chanan Goldschmidt \& Shalom H. Schwartz, Culture, Law and Corporate Governance, 25 Int. Rev. L Econ. 2, 229, sub IV. C. (2005) [hereinafter Culture, Law], holding that without considering countries' cultural region affiliation, the legal family classficiation alone may yield inaccurate depictions of global patterns in corporate governance regimes.

${ }^{11}$ After the ousting of the last Stuarts, the Dutch king (Wilhelm of Oranje) became English king, a development which was due to the strong religious, cultural, and commercial ties between both nations, see JOHN BOWLE, THE UNITY OF EUROPEAN HisTORY - A POLITICAL AND CULTURAL SURVEY 229-231 (OUP 1970).

${ }^{12}$ See Paul G. Mahoney Contract or Concession, 34 Ga. L.R.873, 881-6 (2000): common law would have enabled free incorporation through contracts, while the king's prime source of income in times of colonization was fees for chartering corporations; Detlef Vagts, Comparative Company Law - The New Wave, in FESTSCHRIFT JEAN-NICOLAS DRUEY 598 (Rainer Schweizer et al. eds. 2002).

13 BERMAN, supra note 8, at 9, 285 et seq. Principal changes included, inter alia, the establishment of the independence of the jury as trier of both fact and law, the introduction of the adversary system of presentation of evidence and new rules of evidence.

${ }^{14}$ Reinhard Zimmermann \& Nils Jansen, Quieta Movere - Interpretative Change in a Codified System, in The LAW OF OBLIGATIONS - EsSAYS IN CELEBRATION OF JOHN FLEMING 285, 311 (Peter Cane \& Jane Stapleton eds., Clarendon Press, Oxford 1998). 


\section{Market- and Bank-Centered Economies}

Another common distinction refers to different legal regimes governing financial institutions. Until 1999, ${ }^{15}$ the Glass-Steagall Act of 1933 prohibited American credit banks from engaging in investment banking and the mutual funds industry, as well as from making equity investments in non-financial firms for their own account, while German and Japanese institutions were not restricted in the same way. ${ }^{16}$ A categorization of corporate governance systems relying on this bank-influence is, however, not convincing.

Despite the fact that until $1998^{17}$ German banks influenced their clients through the triad of memberships in supervisory boards, proxy voting and creditor rights, a bank could not effectively exercise this power without risking a backlash by its own supervisory board and shareholder body, as German corporations were traditionally organized in interlocking shareholdings and directorates. ${ }^{18}$ In addition, the influence of banks was weakened because relatively low dividend pressure resulting from underdeveloped capital markets enabled firms to use extensive internal financing, and to forego external financing through the issuance of debt or equity. Further, share ownership of banks is not - and was never extraordinarily high, as one would expect in a bank-centered economy. Shares held by German retail investors usually exceeded bank shareholdings, while non-

15 Through Gramm-Leach-Biley Financial Modernization Act of 1999, see Art Alcausin Hall, International Banking Regulation into the 21 $1^{\text {st }}$ Century: Flirting With Revolution 21 N.Y.L.Sch. J. Int'l \& Comp. L. 41 (2001); Aigbe Akhigbe \& Ann Marie Whyte, The GrammLeach-Bliley Act of 1999: Risk Implications for the Financial Services Industry 27:3 J. Fin. Research 435 (2004).

${ }^{16}$ Mark Roe, Some Differences in Corporate Structure in Germany, Japan, and the United States 102 Yale L.J. 1927, 1948-9 (1992-1993) [hereinafter Some Differences]; a comparative overview over banking regulation provides SIEMS, CONVERGENCE (2005), supra note 7, at 358 et seq.

17 In 1998 the legislature enacted the Gesetz zur Kontrolle und Transparenz im Unternehmensbereich [Law on Furthering Control and Transparency in Corporate Law] v. April 27, 1998, Bundesgesetzblatt, Teil I (1998), 786, which reduced bank-influence by imposing stricter formal conditions on banks organizing proxy voting, as well as by stricter limits and higher transparency of supervisory board memberships and meetings.

18 This caused the legislature to enact in 1965 s. 19 Aktiengesetz [German Stock Corporation Act, hereinafter GSCA], according to which ownership rights in cross-ownerships exceeding $25 \%$ must not be exercised. 
financial corporations held the bulk of the shares in public corporations. ${ }^{19}$ This data is consistent with concentrated ownership, but not with the theory of a bankcentered economy. Banks were part of what has been called "Germany Inc." - a company network that closely tied its members to national economic development, and mitigated competition among its members. ${ }^{20}$ In this network, banks were important and influential, but were neither the center $^{21}$ nor the controlling part. ${ }^{22}$ The same aspect - that banks are involved, but do not control the economy - is true with respect to Japan, where banks belong to, rather than control keiretsu-conglomerates. ${ }^{23}$ Finally, there is some evidence that American banks control important voting stakes of non-financial firms through their trust business, and that American bankers are more likely to join the board of nonfinancial firms of which their bank controls a large voting stake through its trust business. $^{24}$ These characteristics used to be associated with bank-centered economies.

19 A table of share ownership in German corporations is available at Deutsches Aktieninstitut (eds.), Factbook (2006), at www.dai.de (February 26, 2007).

${ }^{20}$ Martin Hoepner \& Lothar Krempel, The Politics of the German Company Network 3, MPIfG Working Paper No. 2003-9, at http://ssrn.com/abstract =494722 (February 26, 2007).

${ }^{21}$ Rather, insurance companies (Allianz AG, Munich Re), which neither provided credit nor exercised voting rights, and industrial conglomerates (Daimler Benz AG, Veba/Viag, RWE/VEW) also held also wide-spread shareholdings. The fourth element of the Germany Corp. were the estates of the founder families (Thyssen, Krupp, Bosch, Siemens, Quandt, etc.). In this structure, bank-plans could indeed falter, for example the plan of forming a car-conglomerate of Daimler Benz AG and BMW AG in 1966. Though the legal details lack precision, for an instructive overview see idem and John W. Cioffi, Restructuring "Germany Inc.": The Politics of Company and Takeover Law Reform in Germany and the European Union, 24 Law and Policy 355 (2002).

${ }^{22}$ Ralf Elsas \& Jan Pieter Krahnen, Universal Banks and Relationships with Firms in THE German Financial System 197 (Jan P. Krahnen \& Reinhard H. Schmidt eds., OUP, $2^{\text {nd }}$ ed. 2004) and Roe, Some Differences, supra note 16, at 1945 show that with respect to the role of banks as monitoring investors, the evidence does not unanimously support a special role of banks for large firms. Joao A.C. Santos \& Adrienne S. Rumble, The American Keiretsu and Universal Banks: Investing, Voting and Sitting on Nonfinancials' Corporate Boards 80 J. Fin. Econ. 419 (2006) show similar structures for the U.S.

${ }^{23}$ Id. Specifically on the role of keiretsu-banks, see J. Mark Ramseyer, Cross-shareholding in the Japanese keiretsu, in CONVERGENCE AND PERSISTENCE 348 (Gordon \& Roe eds. 2004) and SIEMS, CONVERGENCE (2005), supra note 7, at 367 et seq.

${ }^{24}$ Santos \& Rumble, supra note 22, at 11 et seq. show that, in 2000, American banks control on average $10 \%$ of the voting rights of S\&P 500 non-financial firms, including several firms in which banks exercise $20 \%$ to $60 \%$ of the voting rights through their trust business. This evidence is consistent with that provided by R.M. SOLDOFSKY, InstituTIONAL HOLDings OF 


\section{Shareholder vs. Stakeholder Primacy}

Economists have shown that the interests of different stakeholder groups conflict in particular circumstances. ${ }^{25}$ Based on this premise, they demand that the law determines whose interest management should primarily pursue. Most likely due to the legislatures' reluctance to articulate clear statements on this politically explosive issue, ${ }^{26}$ and the paucity of case law, ${ }^{27}$ the American legal literature responded in a fragmented way to the economists' demand. ${ }^{28}$ Hansmann \&

COMMON StOCK, 1990-2000: History, PROJECTION, AND InTERPRETATION (Ann Arbor: Bureau of Business Research, University of Michigan, 1971). It counters Mark J. Roe, Political and Legal Restraints on Ownership and Control of Public Companies 27 J. of Fin. Econ. 7 (1990), who posits that banks were restrained from holding significant equity stakes in firms through their trust department. S.D. Prowse, Institutional Investment Patterns and Corporate Financial Behavior in the United States and Japan, 27 J. of Fin. Econ. 43 (1990), argues that American banks would be required by law to vote in the interest of the beneficial owners. This, however, is also the position under German law.

${ }^{25}$ Michael C. Jensen \& William H. Meckling, Theory of the Firm: Managerial Behavior, Agency Costs and Ownership Structure 3 J. Fin. Econ. 305, 310 (1976); ALFRED RAPPAPORT, CREATING SHAREHOLDER VALUE: THE NEW STANDARD FOR BUSINESS PERFORMANCE (New York: Free Press, 1986). These conflicts include 1. insolvency: shareholders - creditors; 2 . reduction of production: shareholders - workers; 3. geographical investment strategy: shareholders - state; 4 . environmental aspects of production: shareholders - public; etc.

${ }^{26}$ The German legislature in its “official interpretation” of the German Stock Reform Act of 1965 mentioned that corporations should not oppose the interests of the overall economy and the interests of society, while they should, among other interests, also regard interests of employees, see Bruno Kropff, Aktiengesetz [Stock Corporation Act] 97-98 (1965). However, this statement needs to be considered in the light of the "social welfare" clause of s. 70 of the German Stock Corporation Act of 1937, which bound corporations to merely pursue social welfare projects. The German majority opinion holds that corporations may and shall pursue shareholder interests, as long as management balances these interests with diverse interests of other stakeholders, see Peter O. Mülbert, Shareholder value aus rechtlicher Sicht [Shareholder value from a legal perspective], ZEITSCHRIFT FÜR UNTERNEHMENS- UND GESELLSCHAFTSRECHT (ZGR) 129, 156 (1997).

${ }^{27}$ For the United States, see Dodge v. Ford Motor Co., 204 Mich. 459 (1919), implicating shareholder primacy; however, the case has often been understood as a controlling shareholder vs. minority case, see the in-debth analysis by Amir N. Licht, The Maximands of Corporate Governance: A Theory of Values and Cognitive Style 29 Del. J. of Corp. L. 649, 689 (2004) [hereinafter the Maximands]. The German Federal Supreme Court in BGHZ 64, 325, 329 has used the expression "interests of the enterprise," which commentators have interpreted as abbreviation for a behavior whose guidelines are the existence and long-term rentability of the firm, see HÜFFER, AKTIENGESETZ [STOCK CORPORATION ACT] $\S 76$ Rn. 13 ( $7^{\text {th }}$ ed. 2006) with further references.

${ }^{28}$ The majority of American scholarship posits shareholder primacy models, purporting that the primary goal of the public corporation ought to be maximizing shareholders' wealth, and that the reduction of agency costs as central economic problem should be addressed by imposing duties of loyalty and care owed by directors and managers to shareholders, see, for example Lucian Arye Bebchuck, Federalism and the Corporation 105 Harv L.R. 1435, 1451 (1992) (implicitly); 
Kraakman nevertheless confined their categories by contrasting American shareholder primacy with what they perceive to be the leading principles of other corporate governance models. These apparent leading principles include the strong influence or primacy of managers (historically in the United States), workers (Germany), or the state (France and Japan) in the firm. This categorization achieves dubious results, as a closer look at France and Germany illustrates. $^{29}$

Hansmann \& Kraakman categorize the French economy as being statedriven due to the state's involvement in corporate affairs, and the replacement of shareholder suits with criminal sanctions for directors' malfeasance. ${ }^{30}$ Doing so, they focus exclusively on a tiny excerpt from French corporate governance politics. The French state interferes sometimes ${ }^{31}$ with strategic decisions with the

Bernard S. Black, Shareholder Passivity Reexamined 89 Mich. L.R. 520 (1990); Victor Brudney, Corporate Governance, Agency Costs, and the Rhetoric of Contract 85 Colum. L.R. 1403 (1985); FRANK EASTERBROOK \& DANIEL R. FISCHEL, THE ECONOMIC STRUCTURE OF CORPORATE LAW 35 (1991); Ronald J. Gilson \& Reinier Kraakman, Reinventing the Outside Director: An Agenda for Institutional Investors 43 Stan. L.R. 863, 879 (1991); Henry G. Manne, Mergers and the Market for Corporate Control 73 J. Pol. Econ. 110 (1965).

In contrast, stakeholder models assume management should take into account interests of various stakeholder groups, see for example Margaret M. Blair \& Lynn A. Stout, A Team Production Theory of Corporate Law 85 Va. L.R. 247 (1999); Marleen A. O’Connor, Organized Labor as Shareholder Activist: Building Coalitions to Promote Worker Capitalism 31 U. Rich. L.R. 1345 (1997) and The Human Capital Era: Reconceptualizing Corporate Law to Facilitate Labor-Management Cooperation 78 Cornell L.R. 899 (1993); Duncan McLaren, Global Stakeholders: Corporate Accountability and Investor Engagement 12 Corporate Governance: An International Review 191 (2004); Kent Greenfield, The Place of Workers in Corporate Law 39 B.C. L.R. 283 (1998); David Millon, Default Rules, Wealth Distribution, and Corporate Law Reform: Employment at Will versus Job Security 146 U. Pa. L.R. 975 (1998) and New directions in Corporate Law: Communitarians, Contractarians, and the Crisis in Corporate Law 50 Wash. \& Lee L.R. 1373 (1993) and Theories of the Corporation 2 Duke L.J. 201 (1990), and the essays in Progressive Corporate LAW (Lawrence E. Mitchell ed., 1995).

This discussion goes back to the 1930's, see E.M. Dodd, For Whom Are Corporate Managers Trustees? 45 Harv. L.R. 1145 (1932); A. Berle, For Whom Corporate Managers are Trustees: A Note 45 Harv. L.R. 1365 (1932).

${ }^{29}$ Hansman \& Kraakman, The End, supra note 6, at 449 et seq.; the authors borrow heavily from Lawrence A. Cunningham Commonalities and Prescriptions in the Vertical Dimension of Global Corporate Governance 84 Cornell L.R. 1133, 1136 (1999).

${ }^{30}$ Hansmann \& Kraakman, The End, supra note 6, at 446-447.

${ }^{31}$ While the creation of "national champions" by the French Government indeed occurs (examples include the merger of Sanofi-Synthelabo S.A. and Aventis S.A. Currently, EADS / Airbus is in the focus of French politics. French policy understands its measures as anti-takeover regulation by creating size against imperialistic American firms, most of which have strong anti- 
potential for having a national impact, rather than with day-to-day business. Consequently, it is very likely that a non-state mechanism for day-to-day control of the firm exists, which Hansmann \& Kraakman do not examine. Moreover, criminal sanctions are not exclusively a French phenomenon. The criminal proceedings following the scandals associated with Enron, Worldcom and Tyco illustrate this argument.

With respect to Germany, Hansmann \& Kraakman's consider worker codetermination to be the most salient characteristic. Their emphasis on German workers' co-determination, however, is methodologically flawed. Firstly the German Constitutional Court held that the final decision of the supervisory board must eventually lie in the hands of shareholders as property owners (or their representatives), ${ }^{32}$ while clear authority on this point does not exist in U.S.American law. Moreover, pursuant to the most relevant co-determination regime for large public corporations, ${ }^{33}$ shareholders and workers elect an equal number of supervisory board members. However, one of the worker representatives is an officer of the firm, and will typically represent management's interests in practice. Furthermore, if there is a tie in the first vote on a proposal, the chairman of the board (who is a shareholder representative) will have two votes in a second vote,

takeover devices which cannot be exercised under mandatory Continental European corporate laws.), it does not so in all cases, as the successful takeover of Euronext by the NYSE demonstrates

32 BVerfG of 01.03.1979 - 1 BvR 532, 533/77, BVerfGE 50, 290, 337 - Mitbestimmung -.

${ }^{33}$ German corporate law provides for three relevant types of co-determination regimes. The oldest and most extensive co-determination regime, though the least relevant today (with it being used by approximately 20 firms, including ThyssenKrupp AG) is the regime pursuant to MontanMitbestimmungsgesetz of 1951 (and Mitbestimmungsergänzungsgesetz of 1956) which merely regards corporations in mining industries and steel production. Supervisory Boards under this regime have 11, 15, or 21 members, of which shareholders and workers elect both the same number. One member of the employees' bench is an officer of the corporation. The eleventh, fifteenth, or twenty-first member will be elected by shareholders on a proposal by the whole supervisory board (in which shareholder and workers are equally represented), for details see s. 8 Montan-Mitbestimmungsgesetz of 1951.

Furthermore, under the co-determination regime pursuant to Mitbestimmungsgesetz of 1976 for corporate groups with more than 2000 workers, workers elect half of the 12, 16, or 20 supervisory board members. See, in particular, ss. 27, 29 (2) MitbestG 1976.

Finally, the co-determination pursuant to Drittel-Mitbestimmungsgesetz of 2004 regards corporate groups with more than 500 and up to 2000 workers. Under this regime, a third of the supervisory members will be elected by workers. 
thereby tipping the balance in favor of the owners. Since worker representatives are aware of this mechanism, they tend to avoid contentious votes by co-operative arrangements with the owner's side. Further, they try to split the owners' bench and gain influence through (sometimes tainted) information about the employees' suggestions and discussions in board committees. Given these implications, codetermination does not necessarily result in pro-labor decisions by the board. In fact, it is quite the opposite, since conflicts among owners are typically settled outside of the board room. ${ }^{34}$ Despite the proportional worker representation on supervisory boards, shareholder interests are routinely paramount. ${ }^{35}$

Coining the German economy as a "labor-oriented model" is apt to overlook other important aspects of corporate governance in Germany. Some of these include the vital questions which ask why shareholders invest in structures with concentrated ownership, and why dispersed shareholders, which held $45 \%$ of all shares when the structures of worker co-determination were first enacted by democratic devices, did not resist these structures. ${ }^{36}$

Furthermore, Hansmann \& Kraakman's assertion that the present American model would be the most efficient "standard model”" ${ }^{37}$ creates a riddle: why should the present American model be the most efficient - the "End of History”, as they say, of corporate governance development-, while its predecessors have not been? Since legislatures strive for “local optima” through the development of complementarities, ${ }^{38}$ and the legislatures of advanced

\footnotetext{
${ }^{34}$ This does not mean that German co-determination will always result in an owner-favored decision, nor does it mean that the German supervisory board system is without weaknesses. For example, some German supervisory boards are too large (24 members) often resulting in inefficiencies. Labor Unions lobby against a reduction of board sizes since they reap some of the worker members' compensations.

35 Examples include Siemens' and DaimlerChrysler's agreements with worker representatives on increasing the amount of weekly average labor hours from 35 to 40 hours per week, see Reforming Europe's working practices, The Economist of July 29, 2004.

36 The co-determination legislature was enacted in 1950-52. In these years German households held approximately $45 \%$ of all shares in public corporations, see Appendix A, relying on data taken from DAI, Factbook (2006), at www.dai.de (February 26, 2007).

${ }^{37}$ Hansman \& Kraakman, The End, supra note 6, at 440-443.

${ }^{38}$ Lucian Arye Bebchuck \& Mark J. Roe, A Theory of Path Dependence in Corporate Ownership and Governance 52 Stan. L.R. 127, 139 (1999) referring to Mark Roe, Chaos and
} 
countries also have the intellectual and academic capacities to achieve it, why then should the present American system be the most efficient for the entire world? References to relatively short periods of economic superiority ${ }^{39}$ are not persuasive $^{40}$ : To the same extent that current Chinese enticement of international investment (which is likely due to the size of the Chinese internal market, advantageous labor prices and a state-directed monetary policy) does not necessarily prove that American-style corporate governance is inherently flawed, American-style corporate governance was not necessarily superior to Japanese and German-style corporate governance in the 1990s, and so on. Arguments from this "continually shifting debate" 41 are unsuited to support a fundamental categorization.

\section{Explicit and Implicit System of Corporate Control}

I prefer a categorization of corporate governance systems which relies on the primary means with which shareholders influence management. Under this categorization, there are Explicit Systems and Implicit Systems of corporate control. Explicit Systems of corporate control are based on direct influence of present shareholders - majority shareholders through board control, and minority shareholders by engaging in monitoring functions through shareholder meetings. In contrast, Implicit Systems of corporate control are predicated on the efficiency

Evolution in Law and Economics 109 Harv. L.R. 641-643 (1996); Reinhard H. Schmidt \& Gerald Spindler, Path dependence and complementarity in Corporate Governance, in CONVERGENCE AND PERSISTENCE 114, 117 (Gordon \& Roe, eds., 2004).

${ }^{39}$ Hansman \& Kraakman, The End, supra note 6, at 449 et seq.; also, for example, though much more cautious, Roberta Romano, A cautionary Note on Drawing Lessons from Comparative Corporate Law 102 Yale L.J. 2021, 2023 et seq. (1993). An overview of the perennial debate presents, inter alia, Ronald J. Gilson, Globalization of Corporate Governance: Convergence of Form or Substance, 49 Am. J. Comp. L. 329 (2001) and Corporate Governance and Economic Efficiency: When do institutions matter?, 74 Wash. U. L. Qu. 327 (1996).

${ }^{40}$ The fact that the German system was successful in the 1970s, the Japanese in the 1980s and the American in the 1990s, and the Chinese system may be successful in the 2000s, does not establish bullet-proof evidence for the efficiency of corporate governance systems, but for the periodical supremacy of overall economic conditions..

${ }^{41}$ Gilson, Controlling Family Shareholders in Developing Countries, Stanford Law and Economics Olin Working Paper No. 333, 14 (2007), at http://ssrn.com/abstract=957895 (February 26, 2007). 
of the capital, product and labor markets. Shareholder influence is primarily exercised in a mediated, indirect way. For example, while the foundation of the French and German systems is an Explicit System of corporate control, an Implicit System of corporate control prevails in the Anglo-American countries. Moreover, it is maintained that the distinctive criteria has been far clearer in the past, while Western corporate law systems are generally converging towards an intermediate state, the golden mean, which is known as the "hybrid system."42

Details will not be presented here, ${ }^{43}$ but the core distinction itself is important for the further normative argumentation presented in this paper. Three characteristics mark the Implicit System. First, Implicit corporate control requires action beyond the circumscribed enclave of present shareholders and proxies immediately instructed by them. For example, capital market pricing requires activity by present and future shareholders. If there were either no present shareholders selling, or no future shareholders buying, a price could not be set. ${ }^{44}$ Thus, the exit right of shareholders ensured by liquid capital markets is an implicit device. Second, the Implicit System does not require direct contact between shareholders and the company. Rather, if shareholders influence managers, they will do it indirectly, without contacting the firm, talking to management, or otherwise trying to influence their behavior. Direct contact, represented by shareholders' votes, is an explicit, rather than an implicit, device. Finally, in the Implicit System, shares are commercialized, and can be wholly replaced by monetary compensation. In contrast, an Explicit System relies on the assumption that shares represent not only monetary value, but also - positively speaking - an opportunity, or - negatively speaking - a responsibility to influence managers.

42 See Ulrich Noack \& Dirk Zetzsche, Corporate Governance Reform in Germany: The Second Decade, 16:5 EuropeAn Business LAW REVIEW 1033 (2005).

43 See Dirk Zetzsche, Explicit and Implicit System of Corporate Governance - a convergence theory, CBC-RPS No. 0001, 21 et seq. (2004), at http://ssrn.com/abstract=600722 (February 26, 2007).

${ }^{44}$ Financial Intermediaries merely balance a short-term deficiency of sell / buy orders in a stock. 
Thus, while both control systems are based on shareholder decisions and shareholder primacy, the degree of directorial deference that corporate law provides varies significantly. Corporate law in Explicit Systems presumes that directors and shareholders share the power in the corporation. In contrast, corporate law in Implicit Systems allots ultimate power to directors. Direct shareholder influence is merely deemed $a$ part of a "rich array of constraints on directors that also includes markets, private ordering and norms." 45

The Explicit / Implicit distinction challenges the orthodox American explanation as to why Continental Europe lacks developed capital markets, which is that Continental jurisdictions have failed in providing adequate protection to minority stockholders from expropriation either by management or by majority owners and, thus, strong securities markets could not develop. ${ }^{46}$ My theory implies that commentators have overlooked the key complement to implicit shareholder control through security markets, which is the explicit influence

${ }^{45}$ Robert B. Thompson \& Randall S. Thomas, The Public and Private Faces of Derivative Lawsuits, 58 Vand. L.R. 1747 (2004).

${ }^{46}$ See, for example, Theodor Baums \& Kenneth E. Scott Taking Shareholder Protection Seriously? Corporate Governance in the United States and Germany 17 Journal of Applied Corporate Finance 44 (2005); Black, supra note 5, at 804; John C. Coffee, Jr., Privatization and Corporate Governance: The Lessons from Securities Market Failure 25 J. Corp. Law 1 (1999) and Future As History: The Prospects for Global Convergence in Corporate Governance and Its Implications 93 Nw. U. L.R. 641, 644 (1998-1999) [hereinafter Future As History] and The Rise, supra note 1, at 59; Jeffrey N. Gordon, An International Relations Perspective on the Convergence of Corporate Governance: German Shareholder Capitalism and the European Union, 1990-2000, in Convergence And Persistence in Corporate Governance (Jeffrey N. Gordon \& Mark J. Roe eds., Cambridge University Press, 2004), although Gordon accounts for the German convergence towards the American system with the German commitment to EU integration rather than with efficiency considerations; Hansman \& Kraakman, The End, supra note 6, at 443; Charles P. Himmelberg, R. Glenn Hubbard \& Insessa Love, Investor Protection, Ownership, and the Cost of Capital (2000) Col. Bus. Sch. WP (Feb 2000), at http://www.gsb.columbia.edu/faculty/ghubbard/papers/HHL_6_14_ACRO.pdf (February 26, 2007); La Porta et al., Corporate Ownership, supra note 4, at 511; Legal Determinants, supra note 4, at 1131; Law and Finance, supra note 4, at 1113; Investor Protection, supra note 4, at 3; Andrei Shleifer \& Robert W. Vishny, A Survey of Corporate Governance, 52 J. Fin. 737, 750 (1997) (though more cautious with respect to Germany); Romano, supra note 39, at 2023 et seq.

Meanwhile, different opinions are noticeable. For example, RoE, supra note 1, holds that American populist politics are responsible for dispersed ownership; see also Dirk A. Zetzsche, Shareholder Interaction Preceding Shareholder Meetings of Public Corporations - A Six Country Comparison 2 ECFR 107 (2005) with further references in note 4-5. 
exerted by minority shareholders. This is especially true with respect to Continental Europe’s largest economies, namely France and Germany.

While my categorization does not provide the ground for a black-andwhite-distinction, the basic observation on which it is based provides the ground for the remainder of this paper - a greater and lesser willingness to accept market influence vis-à-vis a greater and lesser reliance on direct shareholder influence.

\section{The Roots of Contemporary Corporate Governance Systems -}

\section{An Ethical Theory}

All of the above approaches are of an observational, rather than of an analytical nature. Hence, they do not answer the most urgent question which is why these different categories of corporate governance exist in the first place? Why did policy makers choose different paths when facing the same corporate governance problem, namely, the problem of how to ensure that corporate directors and controlling shareholders conduct themselves appropriately, and refrain from taking advantage of (dispersed) shareholders' lack of control over the assets of public corporations to the detriment of such shareholders? ${ }^{47}$ This paper answers those questions by taking the ethics of the respective societies into account.

\section{Norms Do Matter!}

All of the aforementioned approaches exhibit the weakness that they inherently presuppose the predominance of law. They do so, I purport, due to a home bias: To the same extent that a lawyer primarily regards his own discipline,

\footnotetext{
${ }^{47}$ JoHN H. FARRAR ET AL., FARRAR's COMPANY LAW 301 (Butterworths, London et al $4^{\text {th }}$ Ed.: 1998); Preface $v$ to Klaus J. HOPT ET Al. (EDS.), COMPARATIVE Corporate Governance (OUP 1998); Joel Seligman, Corporations: Cases and Materials 133 (Aspen Law \& Business, 1995). Admittedly, there are many differences in the details of the definition of corporate governance. For example, Shleifer \& Vishny, supra note 46, 737 associate with the expression a relatively narrow meaning, holding that it describes legal issues related to the problem of how equity investors receive a fair return on their investment in public corporations; Frank A. Gevurtz, Corporation LaW § 3.1., 179 (St. Paul, Minn.: 2000) defines governance as "the question of how corporate law allocates power."
} 
a sociologist would possibly first consider social forces at work when observing the same phenomena. However, neither of the aforementioned authors can convincingly argue that factors other than law have not been relevant in shaping corporate law in the past. I believe, in contrast, that a law-based approach cannot alone explain what induces the law to look as it does currently.

Thus, this paper seeks to find explanations for differences in law - by relying on non-legal institutions, such as differing values and social norms. ${ }^{48}$ This brings us to a topic which has been extensively discussed by lawyers ${ }^{49}$ and psychologists, ${ }^{50}$ and was the center of attention at a symposium at the University of Pennsylvania on the relevance of norms in corporate law in $2001 .^{51}$ Do norms matter? In short, literature dealing with the correlation of laws and norms uniformly maintains that there is some interdependency. However, many questions remain as John Coffee aptly stated: “Norms do matter, but exactly when

${ }^{48}$ Social "Values" are the psychological counterpart of the "social norms" with which legal academia deals. Licht, The Maximands, supra note 27, at 657 (2004) defines values as "conceptions of the desirable that guide the way social actors select actions, evaluate people and events, and explain or justify their actions and evaluations." For details see Amir N. Licht, Social Norms and the Law: A Social Institutional Approach 31-37, (March 2005) at http://ssrn.com/abstract =710621 (February 27, 2007) (hereinafter Social Norms).

${ }^{49}$ Since the 1990s the law and economics literature on social norms has grown rapidly. It is not the purpose of this paper to repeat the basic insights of the law and the norms scholarship. For such an overview, see e.g. Licht, Social Norms, supra note 48, with further references at 16.

${ }^{50}$ See John M. Fischer \& Mark Ravizza, Ethics: Problems and Principles (Harcourt Brace Jovanovich 1991); GIlBERT HaRman, THE NATURE OF MORALITY: AN INTRODUCTION to Ethics (OUP 1978); Marc D. Hauser, Moral Minds: How Nature Designed Our Universal SENSE OF Right AND WRONG (Harper Collins, 2006); GILBERT HARMAN, EXPLAINING VAlue and Other Essays in Moral Philosophy (OUP 2000); John Mikhail \& Cristina M. Sorrentino \& Elizabeth Spelke, Toward a universal moral grammar, in PROCEEDINGS, TWENTIETH AnNuAl COnference of the Cognitive Science Society (Morton A. Gernsbacher and Sharon A. Derry, eds., Lawrence Erlbaum Associates 1998).

${ }^{51}$ Daniel Berkowitz, Katharina Pistor, Jean-Francois Richard, Economic Development, Legality and the Transplant Effect, 47:1 EUROPEAN ECONOMIC REVIEW 165 (2003); Robert Cooter \& Melvin A Eisenberg, Fairness, Character, and Efficiency in Forms 149 U. Pa. L. Rev. 1717 (2001); Melvin A. Eisenberg, Corporate Law and Social Norms 99 Colum. L. Rev. 1253 (1999); Edward B. Rock \& Michael L. Wachter, Islands of Conscious Power: Law, Norms, and the SelfGoverning Corporation 149 U. Pa.L. Rev. 1619 (2001); Donald Langevoort, The Human Nature of Corporate Boards: Law, Norms and the Unintended Consequences of Independence and Accountability 89 Geo. L.J. 797 (2001). 
and to what extent remain more problematic issues." ${ }^{52}$ Exactly these more problematic issues will be explored in this section.

The problems start, as Larry Mitchell emphasized, ${ }^{53}$ with the distinction between "norms” and “law”. This paper understands social norms as non-legal institutions, which rely on ethical consent among the respective social group. Norms have something to do with "obligation”, hence feelings about what is wrong and what is right - regardless of immediate benefits, or sanctions, for compliance, or breach of these norms. Norms are internalized values of the society in question. ${ }^{54}$

The very existence of such "obligations" was the subject of extensive research pursued by Amir Licht and his co-authors on the co-relation of social norms and the law. ${ }^{55}$ Drawing on cultural value dimensions identified by psychologists Geert Hofstede ${ }^{56}$ and Shalom Schwartz, ${ }^{57}$ these studies reveal significant differences in values between countries of the Western hemisphere and all others, with respect to the rule of law, corruption, and accountability, all of

52 John C. Coffee, “Do Norms Matter? A Cross-Country Evaluation”, 149 U. Pa. L. Rev. 2151, 2175 (2001).

53 Lawrence E. Mitchell, Understanding Norms 49 Univ. of Toronto L.J. 177, 196 (1999); in contrast to Mitchell's value-based understanding of norms, some authors rely on an understanding of social norms as a non-enforceable set of rules, see, e.g. Eilis Ferran, Corporate Law, Codes and Social Norms - Finding the Right Regulatory Combination and Institutional Structure (Working Paper 2003, on file with author).

${ }^{54}$ Mitchell, idem, at 215, 217.

${ }^{55}$ Licht, The Maximands, supra note 48, at 657 and The Mother of All Path Dependencies: Toward a Cross-Cultural Theory of Corporate Governance Systems 26 Del. J. Corp. L. 147, 173 (2001) and Accountability and Corporate Governance (2002), at http://ssrn.com/abstract =328401 (February 27, 2007) (hereinafter Accountability); Social Norms, supra note 48, and Amir N. Licht, Chanan Goldschmidt \& Shalom H. Schwartz, Culture Rules: The Foundations of the Rule of Law and Other Norms of Governance (2004), at http://ssrn.com/abstract=314559 (February 27, 2007); Licht et al., Culture, Law, supra note 10, at 229.

56 See Geert H. Hofstede, Culture's COnsequences: Comparing VAlues, Behaviors, Institutions and ORganizations Across Nations ( $2^{\text {nd }}$ ed., Thousand Oaks, CA: Sage Publications, 2001) and Hofstede, GeErt AND Hofstede, Gert JAN Cultures AND ORGANIZATIONS, SOFTWARE OF THE Mind: INTERCUlTURAL COOPERATION AND ITS IMPORTANCE FOR SURVIVAL (2 ${ }^{\text {nd }}$ ed., McGraw-Hill 2004).

57 For example, Shalom H. Schwartz, Cultural Dimensaions of Values: Towards and Understanding of National Differences in INDIVIDUALISM AND COLLECTIVISM: THEORETICAL AND METHODOLOGICAL IssuEs 85 (Uichol Kim et al. eds., 1994), cited from Licht's studies. 
which are eminent features for a well-functioning corporate governance system. ${ }^{58}$ Extending this approach, I believe that normative differences also explain the legal differences which we see today among countries within the Western hemisphere.

While doing so, I am aware that "[n]orms are fuzzy."59 "While we seem to have a grasp of the potency of social norms, we still lack understanding of their structure, the factors that cause them to emerge, and their relations with the legal system." ${ }^{60}$ Putting norms, culture and the law in context is even more complicated, as culture is diverse per se, and it is even more so in a cross-border context. Thus, some simplifications are conceded: It is not the intention of this paper to challenge the fuzziness of norms. By virtue of the example of religion, however, this paper might shed some light on two aspects of the relationship of norms and law, which is how norms emerged and how these norms have influenced law-making.

\section{The Normative Pillars of Western Culture}

Assessing the impact of norms on corporate governance requires, first, the refining of specific norms that may be relevant in the context of this paper. Historians recognize three pillars of Western (European) legal tradition. First: The ideal of free and rational thought - a development that is owed to the Ancient Greeks. Second: A neutral state administration designed to pursue the goal of its citizens' "good life," rather than the individual interests of its kings, queens or oligarchs. This ideal was first developed in the Roman res publica, and analysed in Ciceros's de legibus. Third: Christianity. ${ }^{61}$

\footnotetext{
${ }^{58}$ E.g. Licht, Accountability, supra note 55, at 5.3.

${ }^{59}$ Eric A. Posner, Law, Economics, and Inefficient Norms 144 U. Pa. L. Rev. 1697, 1699

${ }^{60}$ Licht, Social Norms, supra note 48, at 5.

${ }^{61}$ BOWLE, supra note 8 , at 85.
} (1996). 
The degree of rational thinking of policy makers and corporate stakeholders on corporate law development ${ }^{62}$, as well as, the impact of an efficient administration on corporate law has been sufficiently considered in the current body of literature. ${ }^{63}$ Despite Harold Berman's ${ }^{64}$ as well as Douglas Branson's thoughtful advice, ${ }^{65}$ modern corporate law scholarship ${ }^{66}$ has neglected to recognize Christianity as the third cultural root of Western legal tradition. ${ }^{67}$ This is particularly unfortunate since "broad similarities are obvious in terms of the relative development and maturity of legal institutions across Europe and the United States.”68 Since these institutions impact particularly on the application or enforcement of law, they, in fact, deserve more attention.

\footnotetext{
${ }^{62}$ This is essentially what historical corporate law scholarship is about; see, in particular, Margaret M. Blair, Reforming Corporate Governance: What History Can Teach Us 1 Berkeley Bus. L. J. 5 (2004) (hereinafter Reforming Corporate Governance) and Locking in Capital: What Corporate Law Achieved for Business Organizers in the Nineteenth Century 51 UCLA Law Review 387, at 423 (2003; Coffee, The Rise, supra note 1; Coffee, Future As History, supra note 46.

${ }^{63}$ See, for example, the landmark work by James M. LANDis, The AdMinistrative Process (New Haven, 1938). His political work instructively illustrate THOMAs K. MCCrAW, Prophets of Regulation 153 (Belknapp Press of Harvard Univ. Press, Cambridge MA: 1984) and Joel Seligman, The Transformation of Wall Street 62, 124 ( $3^{\text {rd }}$ Ed., Aspen NY 2003).

${ }^{64}$ BERMAN, supra note 8, at 373: "Contemporary scholars in all the relevant fields ... have largely neglected to consider the impact of belief systems generally on law."

${ }^{65}$ Douglas M. Branson, Teaching Comparative Corporate Governance: The Significance of "Soft Law" and International Institutions, 34 Ga. L.R. 669, 691 (2000): "The teaching of years of comparative study is that it is the culture beneath the law and behind economic and other institutions that is as or more important than law itself, legal structures, and good governance practices.”

${ }^{66}$ The $19^{\text {th }}$ century legal scholarship was more aware of the impact of ethics on law, see e.g. H. Fick Ueber Begriff und Geschichte der Aktiengesellschaften [About the term and history of corporations] 5 ZEITSCHRIFT FUER DAS GESAMTE HANDELSRECHT 1 (1862).

${ }^{67}$ This might be due to a misunderstanding of the term 'rationality', which sees religion and culture as its anti-thesis. Religion and culture is then merely a historical pre-condition to the dominance of rationality. However, considering ethical roots such as Christianity provides better help in understanding the present state of the law, as opposed to applying principles of rationality to periods in which rationality did not supersede other influences on rule makers, such as ethics (.)

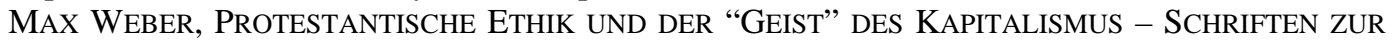
RELIGIONSSOZIOLOGIE I (PROTESTANT ETHICS AND THE “SPIRIT" OF CAPITALISM - TEXTS ON SOCIOLOGY PERTAINING TO RELIGIONS I) I.2., at [62] (1920) (online version by E. Flitner ed., Univ. Potsdam, 1999) [hereinafter Weber, Protestant Ethics] demonstrated with respect to capitalistic beliefs that a rationalistic approach cannot explain, why policy makers pursue some aspects of a generally accepted value, while others are not pursued. Consequently, an ethical analysis of corporate law development might provide insights into the irrational elements of policy making.

${ }^{68}$ Coffee, Future As History, supra note 46, at 645.
} 
The Christian belief is rooted in the (Jewish-based) Pauline doctrine, combining the ideas of human guilt, asceticism, punishment, election, and finally - redemption. ${ }^{69}$ However, the Jewish roots have been significantly changed with respect to its attitude toward market forces and commerce under the influence of the New Testament.

While "[c]ommerce has never been much of a problem for Jews [, $t$ ]he act of commerce, the existence of a commercial society, has always been a problem for Christians."70 Moreover, - an aspect which is disregarded in many works ${ }^{71}$ dealing with the influence of religion on society, despite Max Webers extensive work with respect to this point - when considering the attitudes towards economic activity, the major Christian strands of belief vary significantly, even among Protestant strains of belief.

Catholicism is traditionally critical with respect to the impact of market forces on society. From an historical standpoint, there may be sociological reasons dating back to the fate of the first Christian communities in Ancient Greece and Rome. ${ }^{72}$ As a matter of fact, being particularly concerned with the poor and despising commerce became part of Catholicism's core values. In the $13^{\text {th }}$ century, Thomas Aquinas developed in his "Summa Theologiae" a framework that determined catholic business ethics until 1891 when Pope Leo XIII issued his famous "Rerum Novarum" Encyclical on Capital and Labor. ${ }^{73}$ Under Thomas Aquinas' doctrine, the ethical value of profit and pursue of profit is discussed with regard to the question of whether a person may sell goods at a higher price than the cost of creating the goods. Principally, a contract is fair, when both parties

${ }^{69}$ BOWLE, supra note 8, at 79-80.

70 Irving Kristol, Spiritual Roots of Capitalism and Socialism in CAPITALISM AND SOCIALISM - A THEOLOGICAL INQUIRY 1 (Michael Novak ed. AEI, Washington, D.C., 1979).

71 See, for example, Id..; Rene Stultz \& Rohan Williamson, Culture, Openness, and Finance 70 J. of Fin. Econ. 313 (2003); A remarkable exception is URIEL PROCACCIA, RUSSIAN Culture, Property Rights, AND THE MARKET ECONOMY (forthcoming July 2007).

${ }^{72}$ Kristol, supra note 70 , at 9.

${ }^{73}$ Pope LeO XIII, RERUM NovARUM - EncyCliCAl ON CAPITAL AND LABOR (1891), at www.vatican.va/holy_father/leo_xiii/index.htm (February 26, 2007). 
gain from it equally. If this is not the case in an economic sense, Thomas Aquinas distinguishes between two different types of contracts. First, there are barter deals. If one side of the barter deal is better off, this "profit" is due to the nature of the barter deal, as each side tries to cover its natural needs as effectively as possible. This type of profit is considered to be neutral, from an ethical point of view. On the other hand, profit from cash deals supports an individual's limitless pursuit of power. However, Thomas Aquinas narrowed down the scope of his negative judgement on profits to those businesses that supported primarily the individual's personal desires, rather than the society's needs. Thus, the (intended) use of the profit determines whether profit itself is good or bad. If, for example, the merchant uses his reasonable profit for the maintenance of his house, for charity, or in order to ensure that his country has access to the goods that it needs for survival and development, profit is considered merely to constitute the merchant's salary, and thus not profit in a technical and ethically suspect way. ${ }^{74}$

If profit is, per se, subject to religious restraints, “pure” dealing on capital or product markets, solely motivated by the pursuit of profit, is considered to constitute irresponsible, unjustified activity. ${ }^{75}$ Under this premise, the institution of organized large scale markets was suspicious as it induced human beings to become sinners by forgetting their ethical duties vis-à-vis the community, while striving for their own personal good.

Catholicism retained its difficult relationship with business and commercial activity at least until economists unveiled justifications for (restrained) business (in contrast to unrestrained business as promoted by liberals that adhered to egoism as a virtue) as driving forces for the common good in a dynamic society based on growth. ${ }^{76}$

74 Thomas Aquinas, Summa Theologiae, II-II, Question 77 (4) cited from Arthur Fridolin UtZ, SOZIALETHIK - PART 4 [SOcial ETHICS - PT. IV] 226-8 (Scientia Humana Institut, Bonn: 1994).

${ }^{75}$ UTZ, supra note 74, at 200-5.

${ }^{76}$ With Josef Schumpeter and Walter Eucken being some of the most influential economists with respect to Continental Europe's approach towards business. 
From an economic point of view, the most important difference between Catholicism and Protestantism is Martin Luther's ethical qualification of a believer's occupation. While from a Catholic's point of view, one's occupation is ethically neutral, Protestants understand their occupation as a "calling", and associate the highest value with the fulfilment of their day-to-day duties. Regardless of whether one works as master or servant, all religiously acceptable jobs (this qualification excludes, for example, criminals) have the same positive ethical qualification, while being lazy or idle, in general, are considered sins. ${ }^{77}$ In pursuing their 'calling', it is the duty of Christians to use their will and reason to do as much good and to attain as much understanding of the world and its wordly and spiritual challenges as possible. ${ }^{78}$ Therefore it is the outspoken Protestant ideal that as many Christians (both male and female) as possible are able to read and understand the Bible as the ultimate source of Lutheran belief. ${ }^{79}$

While these religious duties to work and to further one's own scientific and academic progress might explain the greater economic activity and achievements present in Protestant, as compared to Catholic societies ${ }^{80}$, it cannot explain the different economic developments, nor the different approaches with respect to corporate governance systems among Protestant societies themselves. This is particularly true, as significant differences exist between parts of Germany and Scandinavia, on the one hand, and parts of Switzerland, the Netherlands, the United Kingdom and the United States, on the other hand. As table 1 shows, the strands of Protestantism prevailing in these countries differ. LutheranProtestantism prevailed in the former, while Calvinistic-Puritanism's doctrine dominated the culture of the latter.

${ }^{77}$ WeBER, PROTESTANT ETHICS, I.3., at [64-71] and [169-175]

${ }^{78}$ BERMAN, supra note 8 , at 42.

${ }^{79}$ Id. at 64.

${ }^{80}$ The Roman-Catholic belief was predominant throughout the $19^{\text {th }}$ century in all of south, and most of west Continental Europe, besides the Netherlands, the German parts of Switzerland and the North and East of Germany. 


\section{Chart 1: Strands of belief in Europe and North-America ${ }^{81}$}

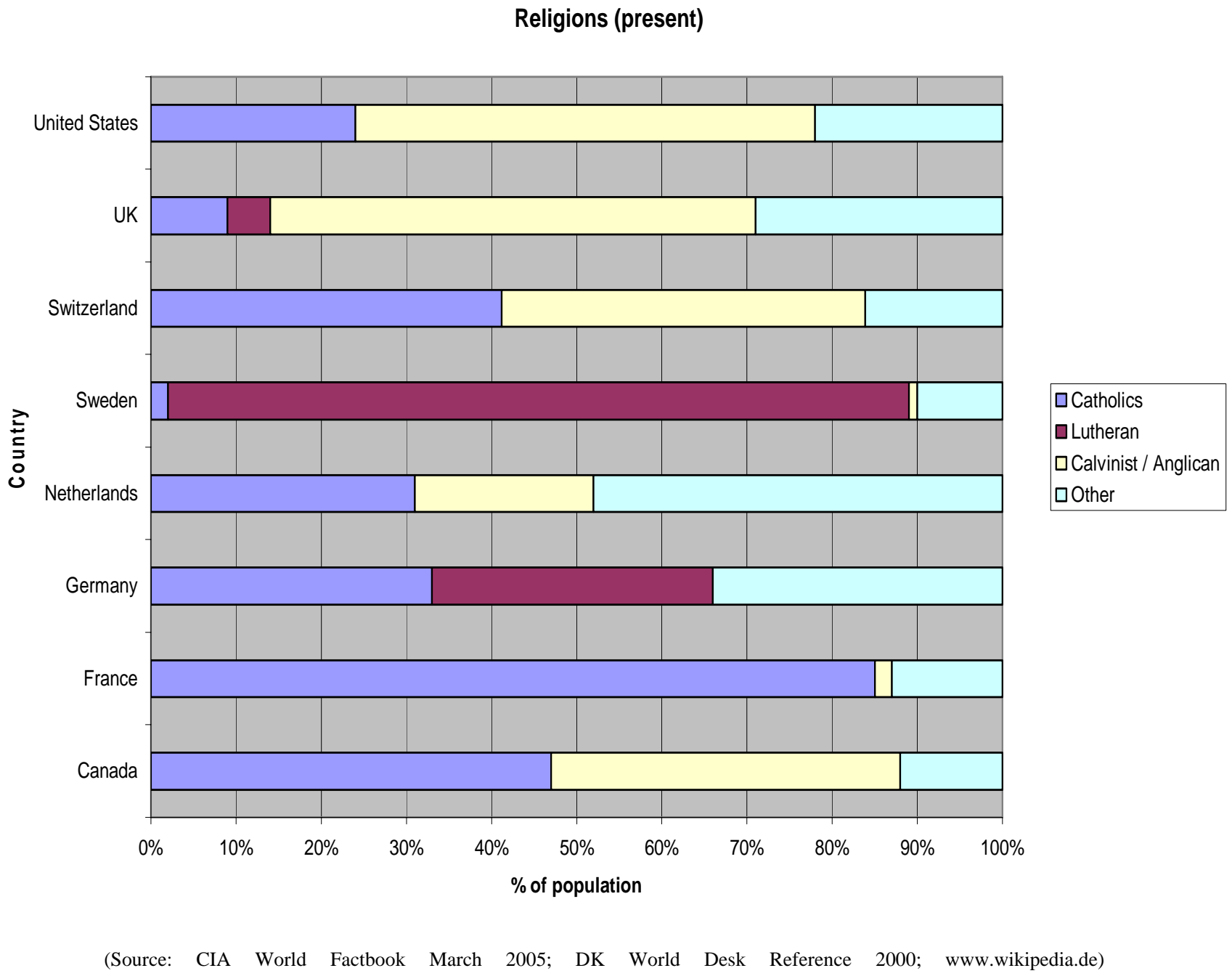

${ }^{81}$ Appendix 1 shows more specific data on religions in Europe and North America. 
Lutheranism and Calvinism differ significantly with respect to their attitude toward market forces and business: While both convictions accept the idea of a calling, they qualify the pursuit of profit differently. Being traditional and dogmatically very similar to Catholicism, ${ }^{82}$ Martin Luther holds that, since the pursuit of profit can only be achieved at others' costs, it is sinful and should thus be left to the heathens. A believer should concentrate on her or his God-given occupation, which she or he must not challenge or change by, for example, improving the tools of production, etc. ${ }^{83}$

Calvinistic-Puritanism, though far from being focused on financial affairs, took a much more world-directed stance. Based on the doctrine of predestination, the distribution of any characteristic, personal good, or idea, is assumed to be God-given. ${ }^{84}$ Consequently, neither wealth, nor its maximization through the pursuit of profit-maximizing opportunities or inventions, is assumed to be sinful. Though riches for the believer's fleshly ends must not ultimately be intended Calvinists denounced such a desire as sinful worship of Mammon -, profitability of the occupation will accrue to God's honour ${ }^{85}$ - unless it results in laziness, since enjoying one's wealth and refraining from work means denying God his dignity and honour, which then results in the foreclosure of one's access to paradise. $^{86}$ The true believer thus worships by pursuing her or his calling. Consequently, in contrast to Lutheran and Catholic societies, wealth maximization by trade or industrial activity is a generally accepted goal in Calvinistic societies. ${ }^{87}$ This must not be misunderstood as legalization of exploitation. The impact of "capitalistic" beliefs is balanced by the communitarian ideal of charity, which imposes duties on the wealthy to share its wealth with the poor, rather than

\footnotetext{
${ }^{82}$ And - since this is derived from the Old Testament - also to the Jewish belief, before the Talmud, see WeBer, Protestant Ethics, I.3., at [74].

${ }^{83}$ Id., at I.3., at [75-79].

${ }^{84}$ Id., at I.3., at [92-93].

${ }^{85} \mathrm{Id}$., at I.3., at [176-177].

${ }^{86}$ Id., at I.3., at [166-172].

${ }^{87}$ BOWLE, supra note 8, at 192; Kristol, supra note 70, at 18 et seq.
} 
to forego opportunities whose use harms others on religious grounds, as Martin Luther and Catholic ethics suggest. Thus, Calvinistic ethics strongly encouraged the development of market institutions that were not subject to state interference.

I hold that the different attitude towards the impact of (capital) markets on society, and thus the different corporate governance systems, which we observe today, is consistent with the various religious backgrounds of societies.

\section{The Diversity Problem}

A theory positing an interrelation between Calvinism and a corporate governance system based on market forces, and Catholicism and Lutheranism and a corporate governance system based on alternative, predominantly explicit means, must pay special attention to inhomogeneous societies. This means: As people are diverse, the ethical identities and values of which they possess are diverse, as well. Thus, an ethical theory of Western ${ }^{88}$ corporate governance history can only be maintained if the relevant ethics cited as explanations for an Explicit or Implicit System of corporate control were, in fact, dominant when policy makers chose the specific development path for their country's corporate governance system.

This section determines the relevant period that business ethics became influential on corporate governance policy. Further, it determines which set of business ethics was prevailing in which country at which point in time.

1. The Industrialization Theory

Corporate governance regimes require corporations. Corporations in the modern meaning did not exist in Europe prior to 1604, when the Dutch-East-India Company was founded. In the first centuries of corporatism $\left(17^{\text {th }}-18^{\text {th }}\right.$ century),

88 The proposition stated herein is strictly limited to Western Europe. It remains to be examined whether the industrialization theory contains a generally applicable principle to the development of other nations' corporate governance systems, as well, such as Japan or China. Given that Japanese society, at least, was heavily shaken by the loss of the Second World War, some exceptions may apply. With respect to China, the observable period of time is too short to whether collaborative elements will be retained when China develops into a social-democratic society. 
companies were semi-public corporations with territorial monopolies. As such, they were predominantly part of the state administration, and only to a lesser degree for-profit-businesses. In contrast, modern corporations were founded in order to ensure appropriate financing for businesses that require significant investment in order to succeed in competitive markets. These investments became necessary, as the end of Mercantilism and scientific progress provided for chances to invest in businesses that employed the many new technologies developed in the period of industrialization (railroads, steam machines, etc.). However, because the polity tends, generally speaking, to respond to crises rather than to prevent them, it takes some time between the occurrence of mass-scale investment and the polity's decision with respect to the way in which it will respond to corporate governance problems resulting from them. Thus, it is reasonable to assume that the specific developmental path that corporate law makers chose for their own corporate governance systems depended upon the religious strain of belief that dominated at the height, rather than the beginning, of the Industrial Revolution. Further, as change is costly - a phenomenon which results in path dependency -, we may assume that the decisions made at the great divide in the $19^{\text {th }}$ century can still be seen in the contemporary corporate governance systems. ${ }^{89}$

\section{Non-Diverse Countries}

From a religious perspective, France, Spain, and Italy were homogenous societies until at least the middle of the $20^{\text {th }}$ century. Traditionally, Spanish and Italian emperors oppressed Protestant tendencies in their home jurisdictions. However, they were less successful with respect to the Netherlands, which were subsequently divided into a Catholic part, later called Belgium, and a Protestant part, the Netherlands of today. The Netherlands will be considered below.

89 Ditto AleXANDER GERSCHENKRON, ECONOMIC BACKWARDNESS IN HistORICAL Perspective: A BoOK of Essays 5 - 71 (Cambridge, MA: Belknap Press of Harvard Univ. Press, 1962); Neil Fligstein, The ArChitecture of MARKets: An ECONOMiC SOCIOLOGY OF TwENTYFirst-Century Capitalist Societies (Princeton: Princeton Univ. Press, 2001). In contrast, Edward L. Glaeser \& Andrei Shleifer, Legal Origins 117 Q. J. Econ. 1193 (2002) trace the origins of legal systems back to the $11^{\text {th }}$ century. 
In the aftermath of the Protestant Reformation, a significant part of the French nobles and merchant citizens became Huguenots - a Protestant strand of belief. However, following the Massacre of St. Berthelemew in 1572, the Catholic French king annihilated, or expelled, most of the Huguenots. Thus, France's population remained almost entirely Catholic from the $16^{\text {th }}$ century through to the very present. Notwithstanding the fact that the French Revolution in 1789 eliminated the strong influence of the Catholic priests on the French legal system, and that French parliament adopted laicism in 1907, 85\% of the French population is still Catholic. ${ }^{90}$

Similar is the situation with respect to the almost purely Lutheran countries of Scandinavia. Interestingly, the Lutheran kings of Sweden were the protectors of Protestantism in $17^{\text {th }}$ century Continental Europe. The values embedded in Lutheranism apparently continue to be influential to this very day.

\section{Diverse Countries}

In contrast, from a religious perspective, we observe heterogeneous societies in the U.S., England, Canada and Germany. Further, Switzerland and the Netherlands provide riddles that remain to be solved.

With respect to the United States, though Chart 1 above shows religious diversity, White Anglo-Saxon Protestants determined American business policy throughout the $18^{\text {th }}$ and $19^{\text {th }}$ centuries. ${ }^{91}$ While some of the Founding Fathers were deeply religious Puritan Calvinists (such as John Adams and Jefferson), others, such us Benjamin Franklin, are more accurately described as Deists and enlightened humanists. ${ }^{92}$ However, these individuals were combined through a

\footnotetext{
${ }^{90}$ Prof. Rauscher mentioned that French socialism and Catholicism have apparently found a way to co-exist. For example, Francois Mitterand, the long-term socialist president of the French Republic, wanted to be buried in the courtyard of the village where he received his first communion. This is consistent with my findings.

91 See Seymour Martin Lipset, Religion in American Politics in CAPITALISM AND SOCIALISM - A THEOLOGICAL INQUIRY 61 (Michael Novak ed. AEI, Washinton, D.C., 1979).

92 Walter Isaacson, BENJAMIN FRANKLIN - AN AMERICAN LiFE 84, 451, 467 (Simon \& Schuster Paperbacks: New York et al., 2004), also describing Franklin's origin and youth in a
} 
common set of values (which Max Weber ${ }^{93}$ inaccurately solely associated with Calvinism), in particular the "concentration on rationalism, on the accumulation of money, on investment, [and ] on asceticism." 94 In addition, the $16^{\text {th }}$ through $18^{\text {th }}$ century Lutherans and Calvinists were strongly communitarian men; Protestant congregations were “close-knit, self-governing "covenanted" fellowships". 95 (It was not until the $19^{\text {th }}$ century that individualism became widely accepted in American society. ${ }^{96}$ ) These characteristics were frequently deemed necessary characteristics for the development of capitalism, as it provides the ground for large organisations that eventually benefit the capitalist shareholders. Moreover, paired with the spirit of Enlightenment, these skills also furthered optimism about education and progress, and thus entrepreneurial success. ${ }^{97}$

Through great waves of Italian and Irish (Catholic) immigrants at the end of the $19^{\text {th }}$ century, Catholicism gained some influence, ${ }^{98}$ but the WASPdominance remains to today. Today, 54\% of Americans belong to Protestantism, most of them to Protestant sects with market ethics equivalent to Calvinist doctrine. $^{99}$

strictly Puritan Boston (at 32) and his practical approach towards Calvinism (at 46); BERMAN, supra note 8 , at 25.

${ }^{93} \mathrm{Id}$., at 72.

${ }^{94}$ Id., at 72; for Benjamin Franklin’s similar values, see Isaacson, supra note 92, at 78, 89, 266.

${ }^{95}$ BERMAN, supra note 8 , at 26; these values became also characteristic for less religious Americans, see for Franklin e.g. Isaacson, supra note 92, at 50, 103, 266, stating that Franklin pushed for "civic cooperation, social compassion and voluntary community improvement schemes".

${ }^{96}$ BERMAN, supra note 8, at 25, calls this the "Decline" of Protestantism.

${ }^{97}$ For e.g. Franklin see Isaacson, supra note 92, at 93 and 266.

${ }^{98}$ In the $17^{\text {th }}$ and $18^{\text {th }}$ century, there were British, French and Spanish colonies in NorthAmerica. British immigrants were predominantly Puritans, while the French and Spanish were Catholics. Even after expansion of the U.S. into the former French and Spanish territories, WASPs were prevailing from an economic, political and a social point of view and superseded the influence of other European and Asian immigrants, see William E. Forbath, Politics, State Building, and the Courts, 1870-1920 in CAMBRIDGE HISTORY OF LAW IN AMERICA - VOL. II 116875 (Michael Grossberg, Christopher Tomlins, eds., forthcoming 2007) (even purporting that Aryan racism were widely spread among the WASP-elite).

${ }^{99}$ Id., at 71-76. 
Conversely, in England, Calvinism-Puritanism never became the established religion. The ethical roots of the Anglican Church were those of Catholicism, in particular, Thomas Aquinas' contract doctrine and the prohibition of usury, the latter in a very wide meaning, as a thirteenth-century manual demonstrates. ${ }^{100}$ From the very beginning, Reformation did not change this antibusiness attitude.. Economic enterprises were damned as a new form of the sin of covetousness. After the Reformation, ”buying and selling, letting and hiring, lending and borrowing, [remained] to be controlled by a moral law, of which the Church was the guardian.” ${ }^{101}$ In practice, in order to retain stability, wages, the entry into a trade, dealings in grain and wood, and many prices for goods were subject to controls, in order to prevent social dislocation. ${ }^{102}$ Further, these principles accounted for interventionist policy in the relationship between farmers and money-lenders in the $16^{\text {th }}$ through the early $17^{\text {th }}$ centuries. ${ }^{103}$

Individualist ideas gained more and more ground in the post-Reformation English Elizabethan society as commercial interests were growing in wealth and influence with the ongoing economic development and expansion of the Commonwealth to overseas. As the divorce between religious theory and economic realities became evident in the $17^{\text {th }}$ through $18^{\text {th }}$ centuries, CalvinismPuritanism became influential in England as it literally captured the industrial and commercial centers, especially London, of England from 1650 through 1680. English Calvinism-Puritanism was the "Second Protestant Revolution" in Europe, ${ }^{104}$ "the true English Reformation, and it is from its struggle against the

${ }^{100}$ See Richard HENRy TAwney, Religion AND the Rise OF CAPITALism - A Historical STUDY 157 (1937) (Penguin Books Ltd., Harmondsworth, Middlesex, England: 1972): “Not only the taking of interest for a loan, but the raising of prices by a monopolist, the beating down of prices by keen bargainers, the rack-renting of land by a landlord, the sub-letting of land by a tenant at a rent higher than he himself paid, the cutting of wages and the paying of wages in truck, the refusal of discount to a tardy debtor, the insistence on unreasonably good security for a loan, the excessive profits of a middle-man - all these had been denounced as usury in the very practical thirteenth-century manual of St Raymond[.]"

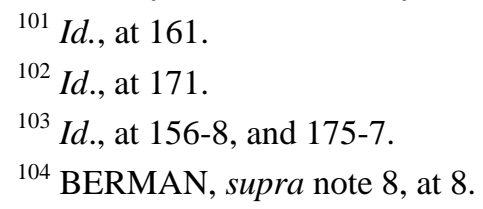


old [Anglican-Catholic] order that an England which is unmistakably modern emerges.”105 The Calvinist business world in the early days of modern England developed its own religious and political ideology and gained influence through its economic power. ${ }^{106}$ Finally, Calvinist business ethics were adopted by the Anglican Church through the back door. Striving for unity in England when facing the threat of a constantly growing Puritan community, the Anglican Church consented to a compromise under which "the bulk of Church property, as well as much preferment” ${ }^{107}$ went into lay hands - i.e. the hands of the bourgeoisie, which was the strong-hold of the Puritan movement. ${ }^{108}$ Hence, to a certain extent, Anglicanism has been captured by Calvinism with respect to the business ethics prevailing. Today, the Anglican Church describes itself as following Evangelical, Catholic, and Liberal traditions, all at the same time. In this regard,, Liberalism is understood as a commitment to "develop Christian belief and practice in order to respond creatively to wider advances in human knowledge and understanding, as well as the importance of social and political action in forwarding God's Kingdom.”109

Canada's population in the $18^{\text {th }}$ and $19^{\text {th }}$ centuries was fed by the French and the British homelands. Still today, both heritages leave their mark on the Canadian legal system. While the British settlers tried to supersede French law in the $18^{\text {th }}$ and $19^{\text {th }}$ centuries, French resistance in Quebec forced British policymakers to allow the Province of Lower Canada the use of its own language and its own laws. It is consistent with Canada's diverse culture that, with respect to corporate governance (and other, particularly social institutions, as well), Canada relies to a lesser degree on market forces ${ }^{110}$ as well as on shareholder primacy ${ }^{111}$

\footnotetext{
105 TAWNEY, supra note 100 , at 199.

${ }^{106} I d$., at 209.

${ }^{107}$ BOWLE, supra note 8, at 192.

108 TAWNEY, supra note 100 , at 190.

109 At www.cofe.anglican.org/about/history/ (February 26, 2007).

110 Zetzsche, Explicit and Implicit System, supra note 43, at B.III.2., and Shareholder Interaction Preceding Shareholder Meetings, supra note 46.
} 
than does the United States. Further, while it is not clear that concentrated ownership is due to a lesser reliance on market forces in Canada (as other explanations may also hold true ${ }^{112}$ ), this observation is (at least) consistent with a, relatively speaking, high level of concentrated ownership in Canada. ${ }^{113}$

Germany has been diverse ever since the times of the Reformation. From 1530 through 1648, European nobles fought on German soil as to whether Protestantism should have a strong-hold in Germany. ${ }^{114}$ In contrast to England, these wars stripped the Bourgeois of their economic power. This is particularly true with respect to the Thirty Years' War (1618-48). This war alone diminished Germany's population by two-thirds. Prussian kings who had lost $75 \%$ of their population in their core-country Mark Brandenburg in 1648, were effectively forced to become tolerant, from a religious point of view, as religious tolerance lured settlers into the deserted regions. Consequently, they invited people from all over Europe with various religious backgrounds to settle in Brandenburg and Prussia.

Following the end of the seven year war in 1763, Prussia became the prevailing power in Germany. At this point in time, the (since 1613) CalvinistProtestant Kings of Prussia ${ }^{115}$ ruled over a Lutheran country with a significant Catholic population remaining. Due to the horrendous experiences of religious wars in Germany, Prussian kings adopted an official doctrine of tolerance and

111 Directors' fiduciary duties are set out in Section 122(1)(a) of the Canadian Business Corporation Act [R.S.C. 1985, c. C-44] and require that directors "act honestly and in good faith with a view to the best interests of the corporation." In its landmark decision Peoples Department Stores Inc. (Trustee of) v. Wise, 2004 SCC 68, [2004] 3 S.C.R. 461 (Oct. 29, 2004), the Supreme Court of Canada confirmed that directors owe their fiduciary duty solely to the corporation, and not to any particular stakeholder group.

112 Ronald J. Daniels \& Edward M. Iacobucci, Some of the Causes and Consequences of Corporate Ownership Concentration in Canada in CONCENTRATED CORPORATE OWNERSHIP 97 (Randall K. Morck, ed. NBER-C 2000).

${ }^{113}$ It does not provide evidence for concentrated ownership, however.

${ }^{114}$ BERMAN, supra note 8, at 57-62 provides a brief overview of events.

115 The Prussian Kings of the family of Hohenzollern were originally from the German region of Baden-Württemberg. 
moderation. ${ }^{116}$ Religious extremes never gained influence over state policy. Their economic approach was Lutheran, as the state's, (not the King's!) rather than any individual's interest, was the promise to which any Prussian citizen was bound. ${ }^{117}$

Since Napoleon's defeat in 1815, Prussian kings handed over governmental powers with respect to specialist topics such as education and business to its well-educated bureaucrats, which turned Prussia into a modern state. While we find both market-friendly Calvinists and market-hostile Lutherans in this bureaucracy, there was never any doubt that the common good of the state was superior to any other individual interest. Calvinist and Lutheran work ethics, marked by discipline, hard labor, and modesty, mixed with a Lutheran pro-state attitude, resulted in an administration, which was strictly autonomous from private interests and local institutions and so efficient, that the later U.S. President Wilson wished to "Prussianize" the U.S. government. ${ }^{118}$

In 1817, the Prussian king forced the reformed Calvinist and the Lutheran churches into a union, ${ }^{119}$ in order to avoid further struggle among different strains of Protestant belief. While, under traditional Protestant belief, the parish substitutes for the (Catholic) Church (as an institution) to which the Christian is responsible, ${ }^{120}$ under the (officially mandated) Prussian united church’s doctrine,

116 The famous Prussian King Friedrich II is said to have been particularly unconcerned by religious debates. When a parish required the King to replace a pastor who denied the existence of doomsday and the phenomenon of resurrection, hence pillars of Christian doctrine, the King wrote back: "If the pastor does not want to stand up on doomsday, he may as well stay asleep. The pastor is to stay!"

${ }^{117}$ For centuries, Prussian kings sought to live up to the ideal of a Lutheran king, whose Calling was to be the "father of the country". According to Martin Luther, a ruler and his high magistracy were bound to the principle of justification, hence religiously obliged to always seek the "just" and "righteous" way, as well. This aspect of Lutheranism did not only impose limits on the subject's rights and duties vis-à-vis his ruler, but also accounted for the doctrine of "civil disobedience" when the ruler commanded the subject to act in evil or immoral ways. For details, see BERMAN, supra note 8 , at 65.

118 Forbath, supra note 98, at 1108.

119 At the beginning of the $19^{\text {th }}$ century (1817), Prussian Lutheran churches founded with other Protestant churches the Evangelical Church of Prussia, an equivalent to, for example, the United Church of Canada.

${ }^{120}$ See for example BERMAN, supra note 8, at 40: "The true church is not a lawmaking institution. It is, rather, the invisible community of all believers, in which all are priests, serving one another, and each is a "private person" in his relation to God. Each responds directly to the Bible as the Word of God.” 
on a nation-wide level the state replaced the parish, while the parish remained important on the local level. Consequently, the church was expected to support the state (again, not the King!), and the state ${ }^{121}$ was supposed to fulfill the functions which were formally exercised by the parish, hence taking the responsibility for the poor and the weak. This implied a greater concern for the public good, and a lesser acknowledgment of individualism. In fact, the united Protestant Church in Prussia adopted more Lutheran than Calvinist values. This might explain the exodus of many Calvinists to North America in the time following this period.

When Prussia merged in 1871 with Catholic states in southern Germany into the German Reich, the collectivist and interventionist business approach, which was consistent with both Lutheran and Catholicism, was retained (at least until the end of the First World War in 1918). Thus, even though the German population was diverse in times of industrialization, business politics were primarily interventionist and collectivist, -characteristics that are consistent with Lutheran and Catholic business ethics. However, the Calvinist influence may explain why market forces were not damned, per se, but kept under control - as is the pre-eminent type of regulation during the German Wirtschaftswunder in the second half of the $20^{\text {th }}$ century, which has become famous under the term social economy.

In the Netherlands, in contrast, Calvinism prevailed in business and economic development, driven by the Protestant conviction that "strenuous toil is acceptable to Heaven.” Proverbial have become "those Dutch Calvinists whose economic triumphs were as famous as their iron Protestantism - 'thinking, sober, and patient men, and such as believe that labour and industry is their duty towards God.”"122 Meanwhile, the strong presence of atheists blurs the picture of Dutch Protestantism, which is probably due to the fact that the Dutch Reformed Church

\footnotetext{
${ }^{121}$ This aspect may explain why Germans and Americans associate different functions and characteristics with the expressions "the State" and "the Government", for details see Ralf Michael \& Nils Jansen, Private Law Beyond the State? Europeanization, Globalization, Privatization, Duke Law School Legal Studies RPS No. 137, at 12-5 (2007).

${ }^{122}$ TAWNEY, supra note 100, at 211.
} 
collects taxes from its members. Dutch Protestants traditionally live in the North of the country, in the industrious harbour cities of Amsterdam, Rotterdam and the like, while Catholicism has its strong-hold in the agrarian regions of the South.

While in Switzerland, Catholicism slightly prevails, almost equals the Protestant population in numbers, its $42.7 \%$ Protestant population with a strong Calvinist influence prevails in Swiss business ethics. The productive cities of Geneva, Bern, Zürich and Basel are primarily Calvinist regions (with Geneva being the first Calvinist city in the world), while primarily agrarian cantons represent the Catholic population. ${ }^{123}$ This proportion remained relatively stable over time as, apparently, Swiss population rarely migrates into cantons of a different cultural background.

\section{The Evidence}

\section{Historical Evidence}

\section{From Medieval Times to Industrialization}

The aforementioned ethical differences with respect to market forces can be traced through philosophical and political literature. ${ }^{124} \mathrm{~A}$ brief look at the diverse fates of colonial undertakings, as well as the policy regarding speculative bubbles in corporate stocks in the years of 1719/1720 exemplifies the way in which religion has influenced corporate law development.

First: the theory of a pro-business attitude in the Calvinistic belief is consistent with the success of colonial undertakings in the Netherlands and

123 Schweizer Bundesamt für Statistik [Swiss Federal Agency for Statistics], Eidgenössische Volkszählung 2000 - Karte 3.1 [Results of the Swiss Census of the year 2000 Map 3.1] at http://www.bfs.admin.ch/bfs/porta.../publikationen.Document.69601.html (February 26, 2007).

${ }^{124}$ See, for example, the works by John Locke, John Stuart Mill, as well as BENJAMIN FRANKLIN, NECESSARY HINTS TO THOSE THAT WOULD BE RICH (1736) and ADVICE TO A YOUNG TRADESMAN (1748), Works ed. Sparks Vol. II p. 87, against JEAN JAQUES ROUSSEAU, CONTRACT SOCIAL, I. 6. (1762) (emphasizing the "supreme direction of the general will") at www.constitution.org/jjr/socon.htm (February 26, 2007). 
England. ${ }^{125}$ While the Dutch and English East-India companies flourished for almost 200 years $^{126}$ and laid the foundations for British and Dutch colonial empires, colonial companies from Catholic and Lutheran countries were all but successful. For example, the French East-India company, set up in 1624 and renamed as such in 1664, quickly faltered because French Kings focused on Catholic missionary works, rather than on economic development and trade. ${ }^{127}$

Moreover, in the first quarter of the $18^{\text {th }}$ century, a frenzy in corporate stocks developed. Starting in France, the Compagnie des Indes, magnetizing money from all over the continent, promised to invest in, and economically exploit, the area of New Orleans, which was a French colony in North America. ${ }^{128}$ At approximately the same time, the English South Sea Corporation, trying to mimic the wide success of the Compagnie des Indes, promised to exploit territories in the South Sea area. When both bubbles eventually burst, the French and English legislatures dealt with the speculation problem in different ways. The French tried to stabilize the precipitating stock prices by prohibiting trade in the stocks by various means. ${ }^{129}$ All of these measures were (futile) means of reducing the impact of market forces on investors and preventing them from experiencing catastrophic financial failures. In contrast, in accordance with the idea of predestination, English regulators strictly applied the caveat emptor principle,

\footnotetext{
125 These, at times highly profitable, undertakings were organized in a structure that some authors deem the first joint-stock corporations.

${ }^{126}$ The former was founded March $20^{\text {th }} 1602$, received the right of perpetual existence in 1623, and existed until struggles in the aftermath of the French revolution caused its end in 1795. The later dated back to 1613 (Blair Reforming Corporate Governance, supra note 62, holds it was founded in 1600), was perpetually incorporated in 1654, and was liquidated in 1858.

127 See, e.g. Fick, supra note 66, at 45 (transl. by the author): „Rather than building fortresses, the company built Catholic churches; instead of farmers and merchants, priests were sent to the colonies. In fact, trade with pagans, living in the new territories, were prohibited. Thus, it was not surprising that the French East-India company ... became insolvent in 1684, and creditors, as well as, shareholders were at the mercy of the majestic exchequer.”

${ }^{128}$ The details of the Mississippi-Bubble cannot be given here. The following abstract of events is taken from Fick, supra note 66, at 46; Peter Garber, Famous First Bubbles 4 J. Econ. Persp. 35 (1990).

129 They included hindrance of exchange of stocks in real value assets, such as gold, restrictions of monetary export, as well as a mandatory amalgamation of Compagnie des Indes with the partially Crown-owned and financial stabile company Banque Royal.
} 
resulting in spectacular scenes in the London financial district, involving bankruptcy and a number of investors committing suicide.. ${ }^{130}$

\section{The Industrialization Period}

During the industrialization period, many instances reflect the thenprevailing ethics in Anglo-America and Continental Europe.

For example, the regulatory approach to freedom of incorporation in the $19^{\text {th }}$ century reflects the market-friendly and market-hostile attitudes of Western law-makers. Aristocratic state laws had traditionally required an official state act for incorporation [concession system]. Given the enormous amounts of capital needed for industrialization, state bureaucracies faced the impossible task of estimating whether the prospective business was viable, dangerous, or potentially fraudulent, on the basis of papers that entrepreneurs presented when applying for concession. The United Kingdom replaced the concession system in 1844. ${ }^{131}$ The early departure from concession to the contractual approach has been held to be an expression of the English sense of personal and economic liberalism, ${ }^{132}$ since - despite the prohibition of bearer shares - few restrictions applied. Given that $19^{\text {th }}$ century English courts were not particularly concerned with minority shareholder protection, ${ }^{133}$ this liberal-individualistic approach catered to the economic interests of management and controlling shareholders.

From the beginning (1789) at least until the Civil War, American states developed the tradition of local self-government and Jacksonian laissez-faire business policy. ${ }^{134}$ State chartering practice was (even) more liberal than in the

\footnotetext{
${ }^{130}$ The fiscus and the non-invested public, though, benefited from the burst of the bubble proportionally more than in France.

${ }^{131}$ The Joint Stock Companies Registration, Incorporation and Regulation Act of 1844 was upgraded in four legislative steps in the years of 1855 through 1858, and resulted in a system that forced business entities to disclose its limited liability by adding a "limited" to its name. See Mahoney, supra note 12, at 886-892.

${ }^{132}$ Fick, supra note 66, at 55-56.

133 In Foss v. Harbottle, 67 Eng. Rep. 189 (1843), minority shareholder suits were restricted; in Harben v. Phillips, 23 Ch.D. 14 (1883), the Chancery Court denied shareholders a common law right for proxy voting.

${ }^{134}$ Forbath, supra note 98, at 1092.
} 
U.K., given that the legislatures did not seek to protect favored corporations with a semi-public purpose through a restrictive chartering practice, with remarkable effects: By the mid-1820s, the English and American capital markets were about the same size, “even though the English had a century’s lead time.”135 By 1860, most American states had passed general incorporation statutes. ${ }^{136}$ Thus, in the $19^{\text {th }}$ century U.S. and U.K., market forces could work relatively unaffected by early state interference, which implies some early deference to the impact of market forces.

The development in Continental Europe was entirely different. When France (in 1863 \& 1867) and the Northern German states (in 1870) eventually receded from incorporation control, ${ }^{137}$ it was soon replaced by a strict mandatory scheme, rather than by a reliance on freedom of contract (which is today known as “enabling” or "contractarian theory"138 of corporate law). This interventionist policy is consistent with a perceived responsibility to protect whoever is deemed to be in an inferior economic position.

Moreover, the predominant form of business that the polity furthered differed. French and German Policy makers tied entrepreneurs to their businesses through personal responsibility for the corporation's debt. In contrast to the United States and the U.K., (some types of) partnerships flourished in France between 1840 and $1912 .^{139}$ The fact that partnerships were the predominant

135 Christian C. Day, Dispersed Capital and Moral Authority: The Paradox of Success in the Unregulated $19^{\text {th }}$ Century New York Capital Markets, 12 L. \& Bus. Rev. of the Americas 303, 311 (2006); Peter L. Rousseau \& Richard Sylla, Emerging Financial Markets and Early U.S. Growth, 41:4 Explorations in Economic History 1, 6 (2005).

${ }^{136}$ Blair, Reforming Corporate Governance, supra note 62, at 27.

137 Werner Schubert, Die Abschaffung des Konzessionssystems durch die Aktienrechtsnovelle von 1870 (The elimination of the concession system through the stock corporation law reform of 1970) ZEITSCHRIFT FÜR GESELLSCHAFTSRECHT (ZGR) 1981, 285, 292 ff.; SIEMS, CONVERGENCE, supra note 7, at 20 et seq.

${ }^{138}$ For a recent critique of this approach see Michael Klausner, The Contractarian Theory of Corporate Law: A Generation Later, 31 J. Corp. L. 779, 781 (2006).

139 See Naomi R. Lamoreaux \& Jean-Laurent Rosenthal, Legal Regime and Contractual Flexibility: A Comparison of Business's Organizational Choices in France and the United States during the Era of Industrialization 7:1 Am. L. \& Econ. Rev. 28, 35 (2005). 
corporate form is consistent with my theory that Continental policy makers tended to hold business people in a fixed relationship to their business, and required them to bear responsibility for small shareholders and employees. The "winner-takesall” rule that was prevalent in the United States in the same period of time ${ }^{140}$ was antithetical to the Continental approach based on responsibility for the weak and poor.

Similarly, the French politician and famous Huguenot François Guizot ${ }^{141}$ became eternal in the French memory with his quote "Enrichez Vous!” (Enrich yourself!), meant as a measure to spur economic activity in France. In the Calvinist-Puritan United States, this quotation would have hardly persisted for eternity. In order to demonstrate the distance between this Calvinist statement and Catholic ethics of the same time period, the reasons for the Catholic business man Melvissen, the founder of the first German banking corporation, decided to choose the corporate form, are particularly illuminating. Melvissen was not only appreciative of the corporate form due to the intense relationship between capital and entrepreneurial spirit, but also because of its social functions. He believed that the corporation was a collectivist organisation in the sense of social ethics being able to counter destructive radicalism. In particular, Melvissen hoped to mitigate the extreme forces of individualism by choosing the corporate form. In order to ensure the shareholders' responsibility, Melvissen preferred registered shares over bearer shares. $^{142}$

Moreover, the diaries of (Pietist-Lutheran) Otto von Bismarck - the longterm chancellor of the German Reich in the second half of the $19^{\text {th }}$ century - reveal

${ }^{140}$ See, for example, Wiley B. Rutledge, Jr., Significant Trends in Modern Incorporation Statutes 22 Wash. U. L. Rev. 305, 337 (1937).

141 François Guizot (1787-1874), a French academic politician, served the French King Louis Philippe as minister of public instruction (1832-37). He was highly influential after 1840 and became premier in 1847. His government was overthrown in February 1848.

142 Transl. by the author from HANDBUCH DER DEUTSCHEN GESCHICHTE III [MANUAL OF GERMAn HISTORY, PT. 3] 382 (Bruno Gebhardt \& Herbert Grundmann eds., $8^{\text {th }}$ Ed., Stuttgart 1960). 
that his social insurance laws of 1884 were, on the one hand, a strategic strike against social democracy, which gained more and more support in the second half of the $19^{\text {th }}$ century. On the other hand, he accounted for his actions from a religious point of view. To the same extent that aristocracy had traditionally provided food and shelter on religious grounds to the old and weak, thereby fulfilling their religious-based responsibility vis-à-vis their followers, ${ }^{143}$ industrialists were to take on responsibility for those who had sacrificed their lives and health to the industrialist's business.

In 1891, Pope Leo XIII issued his Encyclical "Rerum Novarum"144 in which he deals with the social question. The social question comprises the problem of how policy makers should deal with the problems that industrialization brought to Europe, including mass poverty, exploitation of woman and kids by greedy industrialists and, as a response, the rise of socialism. Given their disregard for religion, Pope Leo XIII felt compelled to counter the socialists. Thus, on the one hand, the Pope praises property ${ }^{145}$ - in the tradition of Thomas Acquinas' law of nature - as it grants the wage-earner the power of disposal that ownership obtains. On the other hand, he emphasized that

if a family finds itself in exceeding distress, utterly deprived of the counsel of friends, and without prospect of extricating itself, it is right that extreme necessity be met by public aid, since each family is a part of the commonwealth. In like manner, if within the precincts of the household there occur grave disturbance[s] of mutual rights, public authority should intervene to force each party to yield to the other its proper due; for this is not to deprive citizens of their rights, but justly and properly to safeguard and strengthen them. ${ }^{146}$

\footnotetext{
${ }^{143}$ Martin Luther admonishes in his letter An den christlichen Adel deutscher Nation [To the Christian Nobility of German Nation] German aristocracy to take on its responsibilities for their dependents, drawing on Jesus’ Sermon on the Mount.

${ }^{144}$ Supra note 73.

145 Supra note 73, No. 5-13.

146 Supra note 73, No. 14.
} 
Pope Leo XIII further noted that the wealthy and the working men are not destined by nature to live in mutual conflict:

Just as the symmetry of the human frame is the result of the suitable arrangement of the different parts of the body, so in a State is it ordained by nature that these two classes should dwell in harmony and agreement .... ${ }^{147}$

In particular, Leo XIII underlined the duties of the firm owner:

... but to misuse men as though they were things in the pursuit of gain, or to value them solely for their physical powers - that is truly shameful and inhuman. Again justice demands that, in dealing with the working man, religion and the good of his soul must be kept in mind. [...] Doubtless, before deciding whether wages axe fair, many things have to be considered; but wealthy owners and all masters of labor should be mindful of this - that to exercise pressure upon the indigent and the destitute for the sake of gain, and to gather one's profit out of the need of another, is condemned by all laws, human and divine. ${ }^{148}$

From a Calvinist point of view, "Rerum Novarum” takes the same interventionist and collectivist approach as traditional Catholic doctrine. Despite its acknowledgment of private property and religion, commentators have seen significant similarities between socialist and Catholic business ethics. ${ }^{149}$ Similarly, the Lutheran German Emperor Wilhelm II is believed to have said: "I would personally like socialists if they were not seeking to replace myself!” These collectivist Catholic and Lutheran ethics were influential on economic policy in Continental Europe, and - to a lesser degree - in England and in Canada.

At the same time, in the U.S. Calvinist-based individualism (which was politically reflected in the "Classical Liberalism”) could maintain its dominance against

147 Supra note 73 , No. 19, contuining “... so as to maintain the balance of the body. Each needs the other: capital cannot do without labor nor labor without capital. Mutual agreement results in the beauty of good order, while perpetual conflict necessarily produces confusion and savage barbarity."

\footnotetext{
148 Supra note 73, No. 20.

${ }^{149}$ See Lipset, supra note 91, at 65-7.
} 
collectivist and social minded Progressives until the $20^{\text {th }}$ century's Great Depression, despite mass immigration from non-WASP-countries, increasingly bitter inequalities and class conflicts. ${ }^{150}$ Even though classical liberals were equally alarmed by labor's and farmers' desire for state protection and by the unprecedented power of the merging large corporations, - legal liberalism, believing that competition was the natural order of economic life, maintained that "[t]he state and the law had to be reclaimed from capture by private interests, whether of labor or capital”151 - it was at the heart of classical liberal doctrine to protect a free and competitive market place. In the post-civil-war-U.S., it did so with the help of the judiciary which construed the common law legal principle of “equality”, hence equal rights and equal opportunities, formally, rather than factually: Every individual was assumed to have the same rights and opportunities, regardless of his/her economic position. Thus, the courts felt compelled to secure that lawmaking was free from class domination by the rich few or the property-less many. ${ }^{152}$ Economically, the liberal approach meant abstention from social legislation and thereby (indirectly) furthering the aggrandizement of capital in big corporations, whose fate laid in the hands of the (rapidly developing) capital markets. Thus, distrust in state-administration and centralized order effectively resulted in a policy which favored grandiosity and enabled "the new private leviathans to prevail." "153

The infamous struggle between egotistic investors - the more popular expression "robber barons" would not stand close scrutiny - and similarly egotistic investment bankers (such as J. P. Morgan) which sought to protect the reputation of their business (administering money for European investors) against the

${ }^{150}$ Forbath, supra note 98, at 1092.

${ }^{151}$ Forbath, supra note 98, at 1097.

${ }^{152}$ Forbath, supra note 98, at 1100, citing examples of state and federal courts striking out anti-labor, anti-work protection and other social legislation, Lochner v. New York (1905) being a prominent example.

${ }^{153}$ Forbath, supra note 98, at 1118. 
former, ${ }^{154}$ is evidence for that tendency. Whether state legislatures did not want, or could not interfere with these developments, is unclear. However, it was exactly these conflicts which spurred innovation on the financial markets, resulting in essentially private investor protection through financial intermediaries and qualitative listing standards of stock exchanges (NYSE). ${ }^{155}$ Rather than collectivist state protectionism (as in Continental Europe), it was the initiative of wealthy, powerful and - potentially - greedy individuals that shaped the design of corporate America in the $19^{\text {th }}$ century. These developments are consistent with my ethical findings above.

\section{Continuation in $20^{\text {th }}$ Century Politics}

In the $20^{\text {th }}$ century, the constitution of the Federal Republic of Germany from 1949, the political roots of co-determination after World War II, and the refusal to implement the suggestions contained in the Segrè-Report by the French and German governments, are milestones in a chain of events that show the significant impact of ethics on corporate law development in Continental Europe.

First: Article 14 of the constitution of the Federal Republic of Germany [Grundgesetz] provides constitutional protection for property rights to which the rights of share owners belong. ${ }^{156}$ Articles 14 (1) and (2) hold:

(1) Property and the right of inheritance shall be guaranteed. Their content and limits shall be defined by the laws.

(2) Property entails obligations. Its use shall also serve the public good.

154 The literature on this part of American history is extensive. See, for a contemporary overview, Day, supra note 135, at 327.

155 See Edmund C. STEDMAN, THE NEW YORK STOCK EXCHANGE; IT'S HISTORY, IT'S CONTRIBUTION TO NATIONAL PROSPERITY, AND IT'S RELATION TO AMERICAN FINANCE AT THE OUTSET OF THE TWENTIETH CENTURY (New York, Stock exchange historical company, 1905; ; reprinted New York: Greenwood Press, 1969). For an overview of the early developments see Stuart Banner, Origins of the New York Stock Exchange, 1791-1860, 27:1 J. Leg. St. 113 (1998).

156 This is constant judicature of the German Constitutional Court, see BVerfGE 4, 7, 30 Investitionshilfe -; BVerfGE 13, 363 - Feldmühle -; BVerfGE 25, 371 - Rheinstahl -; BVerfGE 50, 290 - Mitbestimmung. 
Furthermore, according to Article 20 (1) of the Grundgesetz, Germany is a democratic and social federal republic. Articles 14 and 20 are the result of a consensus of the constitutional convent at Herrenchiemsee in 1948. A lay public would assume that this provision is derived from socialist ideas. This is not, in fact, the case. After the breakdown of the Third Reich, all democratic groups assembled in order to negotiate the provisions of the Grundgesetz. The most influential group was the Catholic Christian group ${ }^{157}$ centered around Konrad Adenauer (who would later become chancellor). Adenauer's belief was rooted in the Catholic social ethics of the $19^{\text {th }}$ century, developed by Steguweit, Wilhelm Marx, and Windhorst. ${ }^{158}$ The main achievement of Catholic social ethics was to distill from the Christian ideal of charity [clemencia] an obligation of the state and its members to support the weaker parts of society, which - in times of industrialization - meant to protect them from the impact of market forces. This approach was consistent with Lutheran beliefs and Germanic traditions, and also found support in left-wing groups, such as the social democrats. Thus, Christian roots underpin the ideological fundament of the German "social economy." The Ahlen-Program of the Christian Democratic Union of 1947 reflects this fundament:

Capitalists striving for profit and power can no longer constitute the essence and objective of this social and economic renewal; it will have to be the well-being of our nation. By adopting a cooperative economic order, the German people shall obtain an economic and social constitution which is commensurate with the rights and dignity of man, serves the spiritual and material reconstruction of our nation, and secures peace at home and abroad. ${ }^{159}$

157 The German Catholics were traditionally organized in the "Zentrums-Partei”, which was renamed the Christian Democratic Union [CDU].

${ }^{158}$ For an introductory overview in English see MARY FULlBROOK, A CONCISE HistORY OF Germany 131, 205 - 219 ( $2^{\text {nd }}$ ed. Cambridge Univ. Press, Cambridge, UK, 2004) (this specific strain of belief is called "Rheinischer Katholizismus" [Catholicism of the Rhine area, referring to a predominantly Catholic, and traditionally wealthy, part of Western Germany.]

159 Translation from YONATHAN RESHEF, “GERMANY”, at courses.bus.ualberta.ca/orga417reshef/germany.htm\#republic (February 26, 2007). 
Second: In the years 1951 through 1956, the Christian Conservatives under Konrad Adenauer, Ludwig Erhardt and Alfred Müller-Armack implemented (in coalition with the Liberals) co-determination regimes. ${ }^{160}$ While co-determination was partially intended to be a device used to control industrialists, who had supported the Third-Reich Nazi-regime, ${ }^{161}$ it was also well aligned with the doctrine of ensuring corporate social responsibility (Property entails obligations!) and Catholic doctrine. German Social-democrats, who first participated in government in the late 1960s, did not create the co-determination regimes in the Federal Republic of Germany, instead they expanded them in the 1970 s. ${ }^{162}$ In fact, worker co-determination was first (voluntarily) employed by Catholic capitalists of Western Germany in the second half of the $19^{\text {th }}$ century. ${ }^{163}$

Third,:

“Christian democratic parties ... with powerful Catholic influence behind them, promoted [a] closer European Union: the existing social order was to be saved by a reaffirmation of Christian values in social welfare and rationalized by cosmopolitan big business.”"164

${ }^{160}$ For details on Germany's co-determination regimes see supra note 33.

161 RESHEF, “GERMANY”, supra note 159, at IV., describes the deconcentration policy regarding "heavy industries"; Thomas Raiser, The theory of enterprise law in the Federal Republic of Germany 36 Am. J. Comp. L. 111, 118 (1988) emphasises the teamwork effect of codetermination.

162 The common interpretation of various authors, for example Hansman \& Kraakman, The End, supra note 6, at 443 et seq., that workers' codetermination was an achievement of social democrats or the political left is inaccurate. The fact that a political precursor was enacted in the 1920s in efforts to co-opt revolutionary forces (by social democrats) [see Raiser, id.., at 117] does not explain why a conservative party enacted a co-determination regime in the 1950s. More accurate RoE, supra note 1, at 214: "Germany had an ideological tradition of co-determination, dating from the nineteenth century, when religious groups championed it to soften capitalism, to foster a workplace community without socialism.” Confusing, however, his categorization in mark J. Roe, Political Determinants of Corporate Governance - Political Context, CORPORATE IMPACT 92, 151 (OUP UK 2003).

163 The "Brandt'sche Fabrikordnung" (transl. Rules for the fabrication plant owned by Brandt) in 1890, a code voluntarily adopted by the owner of the plant, the practicing Catholic Brandt, contained a workers body that provided advice to the owner and decided on certain matters with relevance to workers.

${ }^{164}$ BOWLE, supra note 8, at 337. 
The reaction of European states to the Segrè-report ${ }^{165}$ in the 1960 s, which guided the trajectory of Continental European corporate governance, is consistent with John Bowle's above statement. The Segrè-report strongly recommended the development of capital market law, in order to strengthen economic development and competition in the (then) European Economic Community [EEC]. The governments of Continental European nations, however, decided to harmonize and strengthen corporate law by strengthening explicit shareholder rights, rather than by establishing a uniform capital market law. This decision is consistent with the doctrine of the German Stock Corporation Reform Act of 1965, which reduced directorial deference, which the leadership-oriented Stock Corporation Act of 1937, tainted by Nazi-ideology, had embedded within the Act. ${ }^{166}$ This decision was not revised until the United Kingdom entered into the EEC in 1973.

In the U.S., the twentieth century brought regulation of business, but remained, relatively speaking, a liberal economy. Even Roosevelt's collectivist New Deal policy - which American Catholics strongly supported ${ }^{167}$ - does not shatter my theory behind distinction between market-friendly and market-hostile economies, for three reasons: First, the New Deal policy was established after the height of industrialization. At this point in time, financial institutions had reached significant maturity. ${ }^{168}$ Second: the New Deal policy and, in particular, Securities Regulation was officially implemented to provide a fair securities market through a greater level of disclosure (rather than to interfere with market forces

165 EEC-COMMission (ED.), BuILding A EUROPEAN CAPITAL MARKET - REPORT OF AN EXPERT GROUP OF THE EEC COMMISSION (Brussels 1966) (hereinafter Segrè-Report).

${ }^{166}$ Raiser, supra note 161, at 117, refers esp. to s. 70 GSCA of 1937.

167 See Mark A. Sargent, Competing Visions of the Corporation in Catholic Social Thought 1:2 J. of Cath. Soc. Thought (2004), at IV., with further references. Pursuant to Barry Cushman, The Great Depression and the New Deal in THE CAMBridge HistORY OF LAW IN AMERICA sub I, at 14, (Tomlins \& Grossbergs, eds., forthcoming 2007) Jewish and Catholic lawyers facing discrimination in private employment were particular beneficiaries of the expanded administration in the New Deal era.

168 Raghuram G. Rajan \& Luigi Zingales, The Great Reversals: The Politics of Financial Development in the $20^{\text {th }}$ Century (NBER WP 8178, Cambridge, MA: 2001) at http://ssrn.com/abstract $=236100$. 
themselves). ${ }^{169}$ Still today, few U.S. securities laws impose requirements other than disclosure duties and anti-fraud rules (and related sanctions). Third: the New Deal was a period-specific event. The fact that opposing political forces after Roosevelt's resignation could dissolve significant parts of the welfare $\operatorname{administration}^{170}$ is evidence for the thesis that - other than social policy in collectivist Germany and France - the New Deal was not based on a social consensus.

Similarly, the fact that, in the second half of the $20^{\text {th }}$ century, the British labor governments strengthened the social welfare system does not challenge my proposition, for two reasons. ${ }^{171}$ First: I hold that the decisive step was made at the height of industrialization, hence in the U.K. in the early $19^{\text {th }}$ century. In the midtwentieth century, the British financial system was already very advanced ${ }^{172}$ and British corporate law was working for more than a century. Second: since Margaret Thatcher could gather significant support for her turn-around policy in the early 1980's, it is reasonable to assume that Labor's expanding of the welfare state was not based on a social consensus. This argument becomes even more convincing when the recent struggles for reform of the welfare state in collectivist Germany and France are taken into account.

Eventually, even Friedrich A. Hayek underscores the difference between an understanding of individualism that is bound by the limits that society provides, and "true" individualism (of which Hayek was fond). ${ }^{173}$ While French

169 Cushman, supra note 167, sub I., at 10; this aspect spurred criticism by corporate finance experts at the time of the adoption of the Securities Act of 1933, see SELIGMAN, supra note 63, at 71.

170 SELIGMAN, supra note 63, at 213 et seq.

${ }^{171}$ This trend was sharply reversed under Margaret Thatcher in the 1980s. Today, there is very little rightfully deserving of the name social welfare system in the U.K.

${ }^{172}$ Rajan \& Zingales, supra note 168.

${ }^{173}$ Friedrich A. Hayek, Individualism: True and False in: INDIVIDUALISM AND ECONOMIC ORDER 8-9 (The Univ. of Chicago Press, Chicago and London 1948). Hayek tracks this strain of thought through Anglo-American philosophy, including John Locke, Bernard Mandeville, David Hume, Josiah Tucker, Adam Ferguson, Adam Smith, and Edmund Burke. 
and German authors have typically endorsed the former, Anglo-American authors have generally hailed the latter. Thus, different market ethics prevailed in AngloAmerica and in France and Germany.

\section{II. 'Legal' Evidence}

Some differences between Anglo-American and Continental European corporate governance systems are consistent with my finding.

For example, shareholder rights differ across the jurisdictions; in particular, the American corporate governance system assigns significant deference to managerial discretion, ${ }^{174}$ while French and German law traditionally assigns significant influence to the shareholder meeting, in order to balance management influence. ${ }^{175}$ Thus, in 2005, the legal regimes in France and Germany facilitated shareholder monitoring without replacing management. Thereby the laws of Canada and the United States reduced the function of shareholder meetings to an institution dealing almost exclusively with change-incontrol contests. The United Kingdom and Switzerland stood between these extremes. ${ }^{176} \mathrm{~A}$ weak state coupled with deference to market forces is consistent with Calvinism-Puritanism, which prevailed in Anglo-America, while a strong state that aims at balancing and directing the influence of economic power on society is consistent with the Roman-Catholic and Lutheran-Protestant belief. I hold that the inability of minority shareholders in the U.S. to exercise meaningful

\footnotetext{
${ }^{174}$ See Rock \& Wachter, supra note 51. However, the business judgement rule which Rock \& Wachter cite as example is also widely accepted in European corporate law.

${ }^{175}$ Already in the $17^{\text {th }}$ century, French "general assemblies" were dominant. Thus, from the beginning, French and German corporate forms were closer to the "Partnership-ideal" than early British and American corporations. See Bonde, S. 16*; Fischer, Die Aktiengesellschaft (The Corporation) in EHRENBERGS HANDBUCH DES GESAMTEN HANDELSRECHTS III/1 [EHRENBERG'S Manual of Commercial LAW, PT. III-1) 19 et seq. (1916); Lehmann, Entwicklung*, S. 62 f.

${ }^{176}$ See studies by Zetzsche, "Explicit and Implicit System”, supra note 43 and "Shareholder interaction", supra note 46. In 2007, Anglo-America is facilitating day-to-day shareholder monitoring significantly: The SEC allowed for the internet-based distribution of proxy materials. The British Companies Act 2006, which received Royal Assent on November 8, 2006 (available at http://www.dti.gov.uk/bbf/co-act-2006/index.html (February 27, 2007)) also seeks to facilitate the use of internet-based technology in shareholder meetings.
} 
oversight over management other than through a costly management turnover reflects the U.S.-American assumption that capital markets are (semi-strong form) efficient. Canada, under the influence of the U.S. Securities Regulation, adopted similar rules, though Canadian idiosyncracies might have supported a different type of regime. (This is particularly true as the Canadian Supreme Court in his recent Peoples-decision, focusing of the pre-insolvency period, decided against the U.S.-style shareholder supremacy model and in favour of a more collectivist approach.). ${ }^{177}$ In contrast, in France and in Germany, weak capital markets and relatively concentrated share ownership mandated that minority shareholders have the capacity to directly influence directors and large shareholders, as a substitute for the restraining influence of capital markets. With respect to British and Swiss corporations, I found that the laws did not show clear preferences.

These results are consistent with my ethical theory stated above, when adjusted to modern times. Given the values that I assigned to the prevailing religious denominations above, France and Germany are more collectivist, while the United States is more individualistic. The religious proportions in the U.K. and Switzerland can also explain why these countries stand between the collectivist and individualistic societies. Canada constitutes an exception. However, I have previously indicated the reasons for Canadian adherence to market forces, which is access to the liquid American capital markets. American regulators require a certain degree of legal convergence as a precondition for accepting such institutions as the Multi-Jurisdictional Disclosure System (MJDS). ${ }^{178}$

Moreover, it is consistent with my Ethical Theory that, in the U.S., brokers may exercise voting rights on behalf of their clients without having previously

${ }^{177}$ Supra note 111, with further references.

178 The MJDS enables Canadian firms to fulfill they disclosure duties under U.S. law through filing reports governed under Canadian law and filed in the Canadian SEDAR base (the Canadian equivalent of EDGAR). 
received any directions as to how they should vote, ${ }^{179}$ and that $10-20$ percent of the shareholder votes are simply lost in the British chain of intermediaries which leads from the company, over the registrar and the brokers to the shareholders' accounts. $^{180}$

The greater tolerance of Anglo-America towards hostile takeovers ${ }^{181}$ also fits into the picture, as a hostile takeover contest is essentially a market process: Which of the parties can credibly communicate to the shareholders a higher return? Catholic and Lutheran values, such as the responsibility to workers and society, are typically a minor concern in these transactions.

I also find that Katharina Pistor's legal ground rules are consistent with my theory. ${ }^{182}$ Professor Pistor holds that there are liberal market economies (LMEs) and coordinated market economies (CMEs). She shows that there are

${ }^{179}$ A "broker non-vote" generally occurs when a registered broker, who holds securities in street name, has not received voting instructions from his customer having beneficial ownership in the securities. For details see NYSE Rule 451,452, Amex Rule 576, 577, and NASD Rule 2260. Pursuant to NYSE Rule 452, "[a] member organization which has transmitted proxy soliciting material to the beneficial owner of stock ... and solicited voting instructions in accordance with the provisions of Rule 451, and which has not received instructions from the beneficial owner ... by the date specified in the statement accompanying such material, may give or authorize the giving of a proxy to vote such stock, provided the person in the member organization giving or authorizing the giving of the proxy has no knowledge of any contest as to the action to be taken at the meeting and provided such action is adequately disclosed to stockholders and does not include authorization for a merger, consolidation or any other matter which may affect substantially the rights or privileges of such stock.” Rule 402.08 of the NYSE Listed Company Manual defines which proposals may affect substantially these rights. Issuers must report these broker non-votes in Item 4 of Part II of Form 10-Q.

${ }^{180}$ See Paul Myners, "Review of the impediments to voting UK shares - report to the Shareholder Voting Working Group” (1/2004) at http://www.manifest.co.uk/myners/myners.htm (February 27, 2007). The situation is expected to improve with the adoption of the Companies Act 2006, see supra note 176.

${ }^{181}$ See for example Melvin A. Eisenberg, Corporate Law and Social Norms, 99 Colum. L. Rev. 1253, 1287 (1999). In Germany, before the takeover by Mannesmann AG by British Vodafone Plc., not a single hostile takeover attempt succeeded (despite a lack of legal takeover defences in German corporate law). Due to British influence, the European Takeover Directive (Parliament and Council Directive 2004/25/EC on takeover bids, 2004 O.J. (L 142) 12-23) is imposing a liberal approach, in relative terms, requiring fair competition among multiple offerors.

${ }^{182}$ Katharina Pistor, Legal Ground Rules in Coordinated and Liberal Market Economies in Corporate Governance in CONTEXT CORPORATIONS, STATES, AND MARKETS IN EUROPE, JAPAN, AND THE U.S., Pt. III., No. 13 (Klaus J. Hopt \& Eddy Wymeersch \& Hideka Kanda \& Harald Baum eds. OUP: UK 2005) 
social preferences reflected in basic norms, called ground rules. These ground rules became part of a society's legal systems. Today, they can be found in substantive and procedural laws. In particular, with respect to substantive rules, LMEs (which are primarily common law countries) adhere to liberal contractibility and the primacy of individual preference; with respect to procedural default rules, LME-societies believe in universal justiciability and individual initation rights for civil procedures. In contrast, CMEs condition the freedom to contract on the adherence to social norms, or limit it by mandatory provision that reflect these social norms. Further, CMEs provide for selective justiciability and collective initiation rights. As an example for substantive rules, Pistor mentions that "private contracts are valid unless they violate procedural rules and are in "bad faith”", while CMEs require contractors to act in "good faith”, which imposes an ethical standard on the parties. With respect to procedural default rules, Pistor believes that individual initiation rights are typical for LMEs, while the fact that individual litigation rights are limited and frequently delegated to the collective and/or a neutral agent is reflective of CMEs. Pistor holds that the aforementioned legal provisions reflect social preferences.

This paper could add the aspect that Pistor voluntarily refrained from

examining. ${ }^{183}$ That is: what prompted societies to adhere to the specific social preferences, hence ethics, in question? The above ground rules are consistent with my ethical explanations of corporate governance development: In Pistor's terminology, Catholic and Lutheran countries are typically CMEs, while Calvinist countries tend to be LMEs. Interestingly, Canada - a country with both a strong Catholic and Calvinist population - is something in between an LME and a CME.

\section{Empirical Evidence}

As my ethical theory regards both law and ethics, two types of data can, in theory, support or refute my thesis. First, specific corporate governance data, showing that the "responsibility” idea that I generated from Catholic and Lutheran ethics

\footnotetext{
${ }^{183}$ Id., at 8 .
} 
does or does not, in fact, exist; second, data showing the general values prevailing in different societies.

\section{Corporate Governance Data}

If there was - for whatever reason - a greater level of explicit shareholder influence in France and Germany, and a greater level of implicit shareholder influence in Anglo-America, one would assume that current corporate practice should provide some empirical evidence, particularly with regard to the two key assumptions of the Ethical Theory presented above.

First: if capital market control constitutes the core component of AngloAmerican shareholder influence, there is likely some evidence that capital markets are more strongly developed in the United States than in Continental Europe. This first point has been sufficiently examined in former studies to which I refer. $^{184}$

Second: since, according to the foregoing, shareholder meetings constitute the center of the Explicit System, one would assume that there exists some empirical evidence that French and German shareholders are more active through shareholder meetings than are Anglo-American investors. This is, in fact, the case: the attendance rate, measured in votes, at shareholder meetings of the 30 largest German public companies is similar to the attendance rates at those of U.S. American companies, after adjustment for foreign ownership and non-broker votes. However, other figures signal the greater relevance of shareholder meetings in Germany, in particular the (1) greater personal attendance of shareholders at the meeting, (2) the reporting structure, and (3) the average length of shareholder meetings. $^{185}$

${ }^{184}$ For example, Coffee, The Rise, supra note 1, at 15 et seq; Rajan \& Zingales, supra note 168; Zetzsche, supra note 43, at B.III.3. a) (with some minor difference in the data as compared to Coffee's data that are taken from a Dutch dissertation).

${ }^{185}$ Zetzsche, supra note 43, at B.III.3. b) and c). 
These results are consistent with Dunlavy's research, which examines when, and why, the power of individual shareholders has become proportional to their investment, when the "one share - one vote" principle became widely accepted. ${ }^{186}$ Originally, the shareholder was not deemed the owner of a portion of capital, but a "member" of the corporation and therefore an equal among equals. Hence, at the beginning of the century, virtually all, and in 1855, approximately $38 \%$ of the U.S.-American corporations were subject to this "democratic" approach, while already $35 \%$ of the U.S.-American corporations were incorporated with the plutocratic "one share - one vote” principle. In France and Germany, the "one share - one vote” principle was virtually unknown until the end of the $19^{\text {th }}$ century. While in 1884 , “one share - one vote" became the default rule in Germany, charter practice was apparently different. Comparing the German and the American Law, in 1907, a commentator regarded German corporate law to be "exceptionally" democratic (in that sense). ${ }^{187}$ The British law that was similar to the American state laws until the 1860's established in the second half of the $19^{\text {th }}$ century a default rule somewhere in between the democratic and plutocratic approach. These findings are consistent with the ethical theory shown herein as the (Catholic) French and (Catholic/Lutheran) German laws held economic power by large shareholders at bay by virtue of a “democratic" voting pattern, while Calvinism which was prevalent in the U.S. at that time was more open to the exercise of economic power. Even the British compromise fits into that scheme, as its population was partly fond of, and partly hostile to the exercise of market forces.

186 Colleen A. Dunlavy, "From Citizens to Plutocrats: Nineteenth-century Shareholder Voting Rights and Theories of the Corporation", in CONSTRUCTING CORPORATE AMERICA History, Politics, Culture 66, 72, 84-85 (Kenneth Lipartito \& David B. Sicilia eds., OUP 2004) and Corporate Governance in Late $19^{\text {th }}$-Century Europe and the U.S. - The Case of Shareholder Voting Rights in COMPARATIVE CORPORATE GOVERNANCE 5 (Klaus J. Hopt et al., eds. Clarendon, Oxford: 1998).

187 Richard PASSOW, DiE WiRTSCHAFTliche BEDEUTUNG UND ORGANiSATION DER Aktiengesellschaft [The ECONOMic MeAning AND Organization of the StOck CORPORATION] 201 (Jena, Gustav Fischer 1907). 
Further, the data showing Scandinavian countries ahead in the statistics with respect to exploitation of shareholders by management or controlling shareholders ${ }^{188}$ is consistent with Lutheran ethics. This is due to the fact that, on the one hand, Lutheran ethics require the believer to be responsible for the wellbeing of his followers (the traditional Catholic part of Lutheran belief), and on the other hand, imposes duties of hard, strenuous labor and accountability towards the parish (the communitarian-Protestant part of Lutheran belief) on management and controlling shareholders.

It is interesting to see predominantly Catholic countries failing so miserably in these statistics. For example, these statistics show that in France the total vote value as a share of firm value is significantly lower than in any Lutheran or Calvinist country. These statistics have merely been interpreted from a perspective regarding the question as to which family of law (?), either civil or common law, these countries belong, rather than to which strains of belief prevail in each country. Even Stulz \& Williamson, who examined the interrelation of religion, culture and finance, ${ }^{189}$ neglected the difference between the opposing market ethics of Lutheranism and Calvinism, thus mixing further alternative Protestant strains of belief with respect to market ethics.

Professor Coffee used these statistics to state: "The real surprise that emerges ... is the inferior performance of the French civil law countries." ${ }^{190}$ My ethical theory can provide a sound explanation for the inferior performance of France. Let me start with some anecdotal evidence. I come from a wealthy, formerly Catholic region in Western Germany, the Rhein area. The sloppiness of my region's population as well as that of the equally Catholic Bavarians is proverbial in Germany, as compared to the selective Lutheran and Calvinist regions in the Southwest and the North of Germany. One explanation for this is that Catholic ethics are more tolerant with respect to irregularities in business

\footnotetext{
188 Tatiana Nenova, The Value of Corporate Votes and Control Benefits: A Cross-Country Analysis (2000) at http://ssrn.com/papers/abstract=237809 (February 27, 2007).

${ }^{189}$ Stulz \& Williamson, supra note 71.

${ }^{190}$ Coffee, Do norms matter?, supra note 52, at 2162.
} 
behaviour (as compared to the strict and intolerant Calvinist and Lutheran ethics) under the premise that management and controlling shareholders still fulfill their tasks to further the common good. The Catholic practice of absolution, which may be achieved from Priests as a reward for prayer and beneficial behaviour ${ }^{191}$ is, generally speaking, a tolerant principle. Protestants do not know an equivalent, as only faith matters and "forgiveness of sins can be granted only through a direct confrontation between the repentant sinner and God, by divine grace alone, without rules and procedures.”192 Thus, the Protestant sinner must permanently live in a state of terrifying uncertainty as to whether God will forgive his sins and grant him access to paradise.

This explanation of Catholics' tolerance with respect to failures, in general, may find support in the societal organizations of Protestant communities: Protestants did not have a centralized institution (as did the Catholic Church) that exercised spiritual control over the members of the parish. Instead, the parish itself is expected to exert control over its members ${ }^{193}$ and assist them to become "just" and "righteous", in the sight of God. ${ }^{194}$ The fact that a merchant was responsible to the parish for his actions is likely to have furthered the general willingness of Protestants to accept accountability vis-à-vis others. Still today, the term accountability "may invoke strong religious connotations"195 among native English speakers. A similar earthly every-day accountability does not exist in the Catholic belief, since the Catholic Church (hence, the institution) exercised the spiritual control of which the New Testament requires from the Christian. ${ }^{196}$

It is important to note, however, that this doctrine does not allow Catholics to steal. Instead it means that, within the limits provided by mortal sins, relief may

${ }^{191}$ In medieval times, abuses included the sale of indulgences. See BERMAN, supra note 13, at 8: "The pope claimed the power to intercede with God on behalf of sinners in order to remit punishments that otherwise would be inflicted upon them in purgatory after death ..."

192 BERMAN, supra note 8, at 41.

193 BERMAN, supra note 8, at 180, 190.

${ }^{194}$ For the pivotal Protestant doctrine of “justification” see BERMAN, supra note 8, at 41.

195 Licht, Accountability, supra note 55, sub 3.

196 See Proverbs 27:17: “As iron sharpens iron, so one man sharpens another." Galatians 6:1: "Brothers, if someone is caught in a sin, you who are spiritual should restore him gently." 
be granted on earth for sins that, from an individual point of view, justify a failure to abide by the rules. The counterpart of this doctrine is being generous and helpful to the poor - a function which is exercised by the Catholic church on behalf of the individual Christian. The English language provides interesting evidence to this aspect of Catholicism as catholicity equally means ‘permissiveness' and 'generosity’. The statistics mentioned above are, insofar, somewhat lopsided as they only measure permissiveness, and not generosity.

\section{Value-Related Data}

Culture is understood as the values, orientations and underlying assumptions that are prevalent among the members of a society. ${ }^{197}$ Given that the ways in which societal institutions function express cultural priorities, "religion is a convenient proxy for culture.” 198 Hence, studies measuring societal preferences may shed further light on my proposition. In this regard, it is particularly helpful that sociologists and psychologists agree that cultural orientations remain relatively stable and change takes place over time spans of decades and centuries. ${ }^{199}$ In societal preferences, the imprint of ancient intellectual legacies and historical initial conditions may be preserved. ${ }^{200}$ Thus, even though valuerelated data, with regard to the industrialization period is not available, data regarding today's values of societies examined herein may provide some evidence to my thesis.

The reliability of these studies, however, is limited: Firstly, given the diversity of what people associate with certain value-embedding words, there are

${ }^{197}$ Licht, Accountability, supra note 55, sub 5.2.

${ }^{198}$ Licht et al., Culture, Law, supra note 10, sub I. and The Maximands, supra note 48, at 658.

${ }^{199}$ Licht, Goldschmidt \& Schwartz, supra note 55, sub I., V.; Mitchell, supra note 53, at 222.

200 Shalom H. Schwartz \& Maria Ros, Values in the West: A Theoretical and Empirical Challenge to the Individualism-Collectivism Cultural Dimension 1 World Psychologie 99 (1995); Ronald Inglehart \& Wayne Baker, Modernization, Cultural Change, and the Persistence of Traditional Values 65 Am. Sociological Rev. 19 (2000); Shalom Schwartz, Anat Bardi \& Gabriel Bianchi, Value Adaptation to the Imposition and Collapse of Communist Regimes in East-Central Europe, in Political Psychology: Cultural AND CRiss-Cultural Foundations 217 (Stanley A. Renshon \& John Duckitt, eds. Macmillan 2000). 
significant restrictions resulting from statistics measuring value sets. Further, most empirical studies on norms that examine cross-national preferences, either legal or cultural, with regard to religion, do not distinguish between the different strains of Protestantism prevailing in each country, nor do they account for the situation in which there is no one prevailing strain of religious belief, as we observe in Canada, Switzerland and Germany. ${ }^{201}$ Thus, these studies are prone to miss the complexity of religious diversity, even among Western countries. Finally, most empirical studies draw on the classification by, and results of, La Porta et al., ${ }^{202}$ which are deficient in numerous respects. ${ }^{203}$

Considering empirical studies (if only in a very careful manner) nevertheless asserts my proposition: Stultz and Williamson find that creditor rights are weaker in catholic countries. ${ }^{204}$ Notwithstanding that Djankov, McLiesh and Shleifer $^{205}$ do not confirm this result, it would at least not challenge the proposition herein, as a more tolerant Catholic approach towards accountability may go along with a lower moral pressure to pay one’s debt. Daniel Treismann reports a negative correlation between Protestantism and perceived corruption. ${ }^{206}$

201 This is true with respect to research undertaken by Simeon Djankov, Caralee McLiesh, Andrei Shleifer, Private Credit in 129 Countries (2005) NBER Working Paper 11078; Licht, Goldschmidt \& Schwartz, supra note 55; Licht et al., Culture, Law, supra note 10, at 229; Stultz \& Williamson, supra note 71; Daniel Treisman, The Causes of Corruption: A Cross-National Study 76 J. Pub. Econ. 399 (2000).

202 Supra note 4.

${ }^{203}$ LLSV acknowledge several problems with their indices, for example that they do not cover merger and takeover rules nor stock exchange rules or regulations of financial institutions, and they cover disclosure rules only partially, see La Porta et al., Law and Finance, supra note 4. Further, LLSV draw on inaccurate presumptions with respect to shareholder rights, at least with respect to the jurisdictions Germany, Belgium and France, see Sofie Cools, The Real Difference in Corporate Law between the United States and Continental Europe: Distribution of Powers, 30:3 Del. J. Corp. L. 697 (2005). In addition come metholodigal flaws, see Mathias M. Siems, What Does Not work in Comparing Securities Laws: A Critique on La Porta et al's. Methodology 16 ICCLR 300 (2005). Also, one may object to LLSV's choice of index components, to the assignment of equal weight to each, and to the fact that LLSV disregard the general infrastructure of legality, or rule of law, in each country (see Katharina Pistor, Martin Raiser \& Stanislaw Gelfer Law and Finance in Transition Economies, 8 Economics of Transition 325 (2000); Pistor, Patterns of Legal change: Shareholder and Creditor Rights in Transition Economies 1 Eur. Bus. Org. L. Rev. 59 (2000).

204 Supra note 189.

205 Supra note 201.

206 Supra note 201. 
This is consistent with the greater level of accountability Protestant communities are expected to impose upon their members. Admitting a high level of corruption would mean admitting one's failure in keeping the other members of the Parish away from misdeeds. Amir Licht finds that the "cultural attitude [within the U.S.] perceives wealth and power [for the benefit of a single constituency] as desirable values." 207 Psychologists Shalom Schwartz and Maria $\operatorname{Ros}^{208}$ hold that in the U.S., societal preferences for Hierarchy and Mastery legitimate the behaviour of individuals who take advantage of their wealth and power. In contrast, Western Europeans attribute greater importance than Americans to Egalitarianism and Harmony. Rather than with public outcries as in Europe, Americans respond with deference or even admiration to the exercise of power by the mighty and wealthy.

Michael Adams ${ }^{209}$ examined the development of values in the U.S. - a predominantly Calvinist society - and Canada, where Catholic, Lutheran, Calvinist and other immigrant backgrounds converge. According to his results, U.S.-Americans identify themselves with values such as Work Ethic, Patriarchy, Look Good Feel Good, Importance of Brand and Personal Challenge, all of which assigns Adams to the "Status \& Security” quadrant. In contrast, the quadrant captured by Canadians represents values such as Global Consciousness, Cultural Sampling, Ecological Concern, and Brand Apathy. The fact that Americans associate themselves with individualistic-materialistic values, while Canadians if compared with Americans! - prefer collectivist goods, is consistent with my theory. at $685-86$.

${ }^{207}$ Licht, Accountability, supra note 55, sub 5.3, at 38 and The Maximands, supra note 48,

${ }^{208}$ See Schwartz \& Ros, supra note 200, and the interpretation of their results in Licht, Accountability, supra note 55, sub 5.3, at 39; this concept is extended by Licht, The Maximands, supra note 48 , at $681-683$.

${ }^{209}$ See, for example, Michael AdAms, Fire AND ICE - The United StATES, CANAdA AND THE MYth OF ConVerging VALUes 184 (Penguin Group, CA: Toronto: 2003). 


\section{Caveats}

The evidential power of the above is subject to certain limits.

First, it cannot be said with certainty whether religions merely reflect the structure of civil societies who adopted the specific strain of belief. The religion that was adopted for society in the aftermath of reformation depended on which parts of society decided upon the adoption of a particular belief. In Calvinistic societies, wealthy citizens of merchant backgrounds were influential, while in the rest of Europe, feudal structures (still) prevailed. It is thus possible that the choice of religion is merely a proxy for the ruling class itself: Each ruling class can be assumed to have chosen what was most beneficial to itself. This is particularly true with respect to the relationship between Calvinism and the Bourgeois societies in the North and the West of Switzerland, the North of the Netherlands, some important German commercial centers (such as the harbour city of Bremen) and some parts of England and Scotland. ${ }^{210}$ These societies were economically based on trade and commerce rather than farming, and thus could adopt the Calvinist economic approach more readily than other regions. Moreover, since monarchs (rather than cities) typically mandated Catholicism and Lutheranism in the $16^{\text {th }}$ and $17^{\text {th }}$ century - cuius regio, eius religio - the motives of these rulers in choosing religions is easier to determine. Generally speaking, a monarch picked a specific religious belief based on the consequences that the belief had with respect to his or her position in alliances with other monarchs or the Catholic Church. This observation suggests that non-religious criteria played a significant role in selecting religions in the first place.

This consideration, however, does not denounce my theory, as specific religious beliefs have at least heavily influenced the prevailing attitude of the ruling class at a particular point in time. The class who chose the religion was

${ }^{210}$ See BERMAN, supra note 8, at 54, citing Steven Ozment: “The Protestant Reformation presupposed for its success a literate urban culture and seems particularly to have attracted rising urban groups who had experienced or were determined to come into a new political and economic importance." 
thereby trapped in the web provided by their choice. The societies became "path dependent”, given that the values preached by politicians as well as pastors, priests and ministers were internalized by all social classes over time. ${ }^{211}$ Thus, while the specific choice of a religion in the first place might have been due to considerations other than true belief, religion nevertheless became part of the specific societies' ethics over time. This (and nothing more) suggests the ethical theory stated above, and this is also the reason why the theory is, at its core, an ethical, hence normative theory, and not a religious one.

Second, the above does not present evidence with respect to the question of whether other societal values were more influential with respect to corporate governance development than religion. For example, it is possible that the values emphasized herein were an integral part of an efficient state administration ${ }^{212}$ or that democratic traditions in Switzerland and England, ${ }^{213}$ or the entrepreneurial spirit of immigrants in the United States ${ }^{214}$ caused the adoption of specific corporate governance regimes. Further, some commentators suggest that Europe is characterized by statist societies meaning that, generally speaking, European

${ }^{211}$ With respect to models of norm internalization see Robert D. Cooter, Decentralized Law for a Complex Economy: The Structural Approach to Adjudicating the New Law Merchant 144 U. Pa. L. Rev. 1643, 1657 (1996); Amitai Etzioni, Social Norms: Internalization, Persuasion and History, 34 Law \& Society Review 157 (2000); Louis Kaplow \& Steven Shavell, Moral Rules and the Moral Sentiments: Toward a Theory of an Optimal Moral System, Harvard Law and Economics Discussion Paper No. 342 (2001) at http://ssrn.com/abstract=293906 (February 27, 2007); Richard H. McAdams, The Origin, Development, and Regulation of Norms, 96 Mich. L. Rev. 338, 341 (1997); Licht, Social Norms, supra note 48, at 16-20; Mitchell, supra note 53, at 216.

${ }^{212}$ E.g. Melvin Dubnick, Clarifying Accountability in Public Sector Ethics: Finding AND ImPlementing Values 68, 70 (Charles Samford \& Noel Preston \& Carol-Anne Bois eds., 2000) sees the origin of the English accountability principle in the administrative steps by William the Conqueror after the conquest was complete.

${ }^{213}$ Licht, Goldschmidt \& Schwartz, supra note 55, at II.C.3. and V., focus on „democratic accountability“, dating it back to Socrates' unwillingness to escape from prison and the death sentence, since this would undermine the stability of the state; see also Licht, Social Norms, supra note 48 , sub V.D., at 69.

${ }^{214}$ Licht et al., supra note 10, at IV.B.3. show strong preferences in English speaking countries for Mastery and de-emphasis of Harmony, and explain this with frontier experience, active development, and the centrality of entrepreneurial business. 
societies were adverse to change, while the United States' society is antistatist. ${ }^{215}$ Moreover, some ${ }^{216}$ believe that homogeneity versus heterogeneity, hence social cohesion, is the decisive aspect. Other criteria may also exist that weaken the ethical theory presented herein.

In theory, it is possible (but unlikely) that all leading members of the societies analyzed in this paper were atheists or opportunists when deciding on the development of corporate governance systems. It is also possible that, in fact, other influences prompted the developments discussed above. The general question of which factor was most influential is a typical statistical problem that empiricist discuss under the term regression analysis. In an historical setting, however, we cannot gather accurate data with respect to the values of individuals acting in the period of time that is relevant for the ethical theory. Thus, the use of statistical methods is not really helpful, as we are limited to drawing conclusions with respect to the past from what we observe today. This is unfortunate, because European and North American societies look different today than they did at the end of the industrialization period: Two World Wars, the Cold War, and immigration from second and third world countries have impacted on the cultural identity of these societies. It is thus likely that researchers dealing with the topic a century ago had a more accurate picture of which values prevailed in societies in times of industrialization. From that perspective, it is reassuring that, with respect to my general rationale, I find myself in good company: Max Weber held that what is perceived as simply another difference today is, in fact, rooted in the “might of religions." 217

Closely related, but at a second glance, slightly different is the third problem, which is that of causation. While the aforementioned question describes the problem of which value prevails, the problem of causation looks at alternative

215 Irving Kristol, supra note 70, at 2 et seq.; Seymour Martin Lipset, American Exceptionalism in CAPITALISM AND SOCIALISM - A TheOlOGICAL InquiRy 34, 39-40 (Michael Novak, ed., AEI, Washinton, D.C., 1979).

${ }^{216}$ Coffee, Do norms matter?, supra note 52, at 2167.

${ }^{217}$ WeBer, Protestant Ethics, at [81]. 
non ethics-based explanations which might have had similar effects on policy makers. ${ }^{218}$ For example, Europe is one of the most crowded regions of the planet. In the $19^{\text {th }}$ century, all European states had to deal with the reverberations of the Industrial Revolution, characterized by over-population and related social problems (the social question, addressed above). In contrast, North America is a very vast region, and still relatively sparsely populated. Consequently, one could (incorrectly $^{219}$ ) assume that there was little pressure to deal with social problems in the U.S. until the Great Depression in 1929-30. Subject to this premise, one could argue that the severance of the problem, rather than ethics, dictated which path policy makers chose. However, while the large Continental jurisdictions intervened into the markets by requiring mandatory insurance of workers etc., in the UK, which was equally concerned with social problems as Continental states, legislators could not permanently establish a collectivist-protective legislation. Interestingly, we also observed interventionist tendencies in the times following the Great Depression in the U.S. However, similarly to the UK, U.S. American legislators did not generally adopt an interventionist approach. Instead, they still believe in market forces (which is what securities regulation is all about), and are even successful in exporting their belief to other countries.

Finally, the data used for determining the religious preference in each country are a little vague. ${ }^{220}$ There exists few accurate data on religions in the countries that are subject to this survey. While the main streams (Catholic versus Protestants) are typically considered, data is lacking with respect to the sublevels of Protestantism. This is unfortunate, because the thesis developed herein relies on

${ }^{218}$ The causation issue is similar to the question examined by economists whether legal origin (so the Law and Finance Theory) or endowment (Endowment Theory) is more important for developing capital markets, see e.g. Thorsten Beck, Asli Demirguc-Kunt \& Ross Levine, Law Endowments and Finance 70:2 J. Fin. Econ. 137 (2003).

${ }^{219}$ See Forbath, supra note 98, at 1142-58 for the urgency of the Social Question in the U.S. and the struggle between collectivist Progressives and individualist Liberals.

${ }^{220}$ See Appendix 1. 
the differences among certain strains of Protestantism. Nevertheless, I hold that the big picture, which the murky data allows, reveals remarkable consistency.

\section{Intermediate Result}

While this section did not, from a scientific point of view, prove that ethics are the sole force having driven corporate governance development in the past, it suggested that ethics had an important role to play when policy makers decided in favor of one or the other way of encouraging management to remain honourable and appreciative of other stakeholders' property. Within the caveats of this study, it is thus reasonable to assume that the trust or distrust in market forces that is evidenced through certain jurisdictions' corporate governance development over time is characteristic of the religious strain of belief prevailing in the specific jurisdiction.

\section{E. Shareholder Value in the Present and Future: Where do we go}

\section{from here?}

Turning Edmund Burke's phrase ${ }^{221}$ into a positive statement, it is the past that reveals to us how we can shape the future. ${ }^{222}$ What does the ethical theory of corporate governance history implicate with respect to present and future corporate governance policy? Are some regulatory measures unlikely to succeed in corporate governance systems based on Calvinistic ethics, as compared to Catholicism, or Lutheranism, or vice versa? For example, in the Lutheran countries of Norway, Sweden, etc., but also in Germany, data collected by Mark Roe (in Political Determinants) show few diversions of assets by controlling shareholders to the detriment of small shareholders. Is this the result of a legal

221 EDMUND BURKe, REFLECTIONS ON THE REVOLUTION IN FRANCE AND ON THE ProceEding IN CERTAIN SOCIETIES IN LONDON RELATIVE TO THAT EVENT IN A LETTER INTENDED TO HAVE BEen SENT tO A Gentleman In PARIS 96 (1790) (The Harvard Classics) available at www.bartleby.com/24/3/3.html (February 27, 2007): "People will not look forward to posterity, who never look backward to their ancestors."

${ }^{222}$ Pierre Teilhard de Chardin, cited from BERMAN, supra note 8, preface at X. How the past can help shape the future is examined by Michaels \& Jansen, supra note 121, at 41-49. 
regime, or of ethics? Provocatively stated, may we explain inefficient Italian minority protection by reference to Catholicism?

Given the complexity of the issues presented, this section is unable to answer all of these questions, and even with respect to the questions that it does attempt to answer, the analysis results in a sometimes lighter, and sometimes darker, shade of grey, rather than being answered with black-and-white statements positing bright-line distinctions. These, however, constitute typical characteristics of interdisciplinary studies involving social sciences and law.

At the very least, the ethical theory provides an answer to one question in international comparative corporate governance theory which is discussed under the term "transplant effect:" 223 If, in fact, ethics do influence corporate governance efficiency, transferring the legal scheme of one successful corporate governance system to another is unlikely to yield the desired results. ${ }^{224}$ Rather, notwithstanding ethical indifference, the ethical theory suggests that the legal scheme needs to be adjusted to the specific ethical background of the corporate governance system to which it is being transferred.

In this section, I will further focus on three core issues of the contemporary convergence debate. These are the question of "path dependency” (sub I.), the question of which values prevail to what extent in which country (sub II.), and finally, the question of whether and with what implications values converge (sub III.).

\section{Ethical "Path Dependency"}

Some recent statements emphasize the interest in examining whether and to what extent ethics interact with economic forces that may prompt path dependency. According to Mitchell, culture is what economists seek to explain with theories on path dependency; ${ }^{225}$ Amir Licht considers culture to be "the

\footnotetext{
${ }^{223}$ See, for example, Berkowitz, Pistor \& Richard, Economic Development, supra note 51; Nuno Garoupa \& Anthoy Ogus A Strategic Interpretation of Legal Transplants 35:2 J. Leg. Studies 339 (2006).

${ }^{224}$ In the same vein Licht, The Maximands, supra note 48, at 683.

${ }^{225}$ Mitchell, supra note 53, at 233 et seq.
} 
mother of all path dependencies." ${ }^{226}$ For economists, path dependency is a collective action problem: even though the state after adoption of certain legal regimes is expected to be superior, in summa, a society is blocked from adopting these laws in the first place, due to particular interests of groups that either personally benefit from the current detrimental state, or that are unwilling to pay the costs of change mandated by the reform. ${ }^{227}$ On the grounds of my ethical theory, path dependency can be explained through ethical resistance, as well. Even though a state may, from an economic point of view, be considered superior - if you assume rational actors only, putting all ethics aside -, it may not be considered superior from an ethical point of view, as the economically superior state does not cater societal preferences. ${ }^{228}$ This is, for example, the case with respect to the "hire-and-fire" mentality and "predator capitalism" that some Continental Europeans associate with Anglo-American investors. It is simply not consistent with ethics that rely on the principle of responsibility for one's followers to lay workers off, as long as the business itself is doing well. Under these conditions, reforms will be opposed on the grounds of ethical, rather than the individual's economic, concerns. Similarly, even in the absence of minority rights, in a society in which these ethics are commonly accepted, small shareholders may be more willing to trust controlling shareholders (regardless of whether this trust is justified from an economic point of view), given that rippingoff minority shareholders would pose significant risks to the controller's reputation. $^{229}$

Further, path dependency may also be facilitated through the fact that these ethics are embedded into, or even pillars of, the contemporary legal system. This observation is consistent with Katharina Pistor's proposition on ground-rules that

${ }^{226}$ Licht, The Mother of All Path Dependencies, supra note 55.

${ }^{227}$ See the references supra note 38.

${ }^{228}$ Garoupa \& Ogus, supra note 223, at 359 cite these preferences as a basis of resistance which harmonization and unification cannot overcome.

${ }^{229}$ For a reputation-based explanation of the existence of minority shareholders, see Gilson, supra note 41. 
are based on social preferences, ${ }^{230}$ according to which these social preferences are deeply rooted in law and complementary legal institutions, which account for a high level of path dependency. I share her view.

\section{The "Value Graphs"}

Moreover, my ethical theory suggests that we need an ethically adjusted understanding of what "shareholder value" means in each and every country, so that it is possible to accurately evaluate efficiency of legal regimes. As stated above, in Lutheran and Catholic countries, "shareholder value" traditionally includes taking responsibility for one's followers. These values can hardly be measured, from an economic point of view. Chart 4 and 5 nevertheless (try to) outline which, and to what extent, other values are added to the uniform goal of corporations to make profits in each of the countries' corporate governance systems.

\section{Chart 4}

\footnotetext{
230 Pistor, supra note 182.
} 
Values I: Collectivism $<>$ Individualism (present)

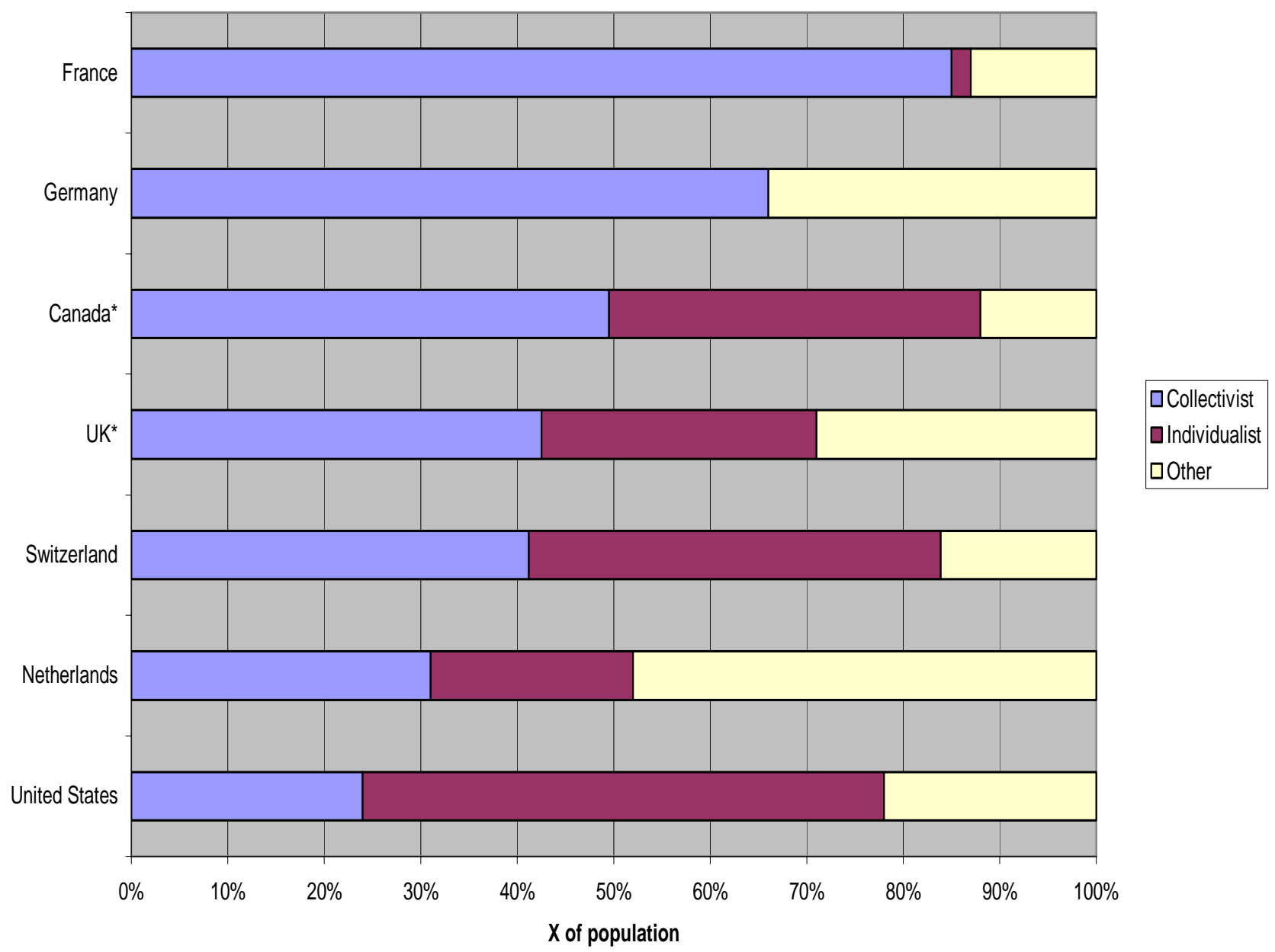




\section{Chart 5}

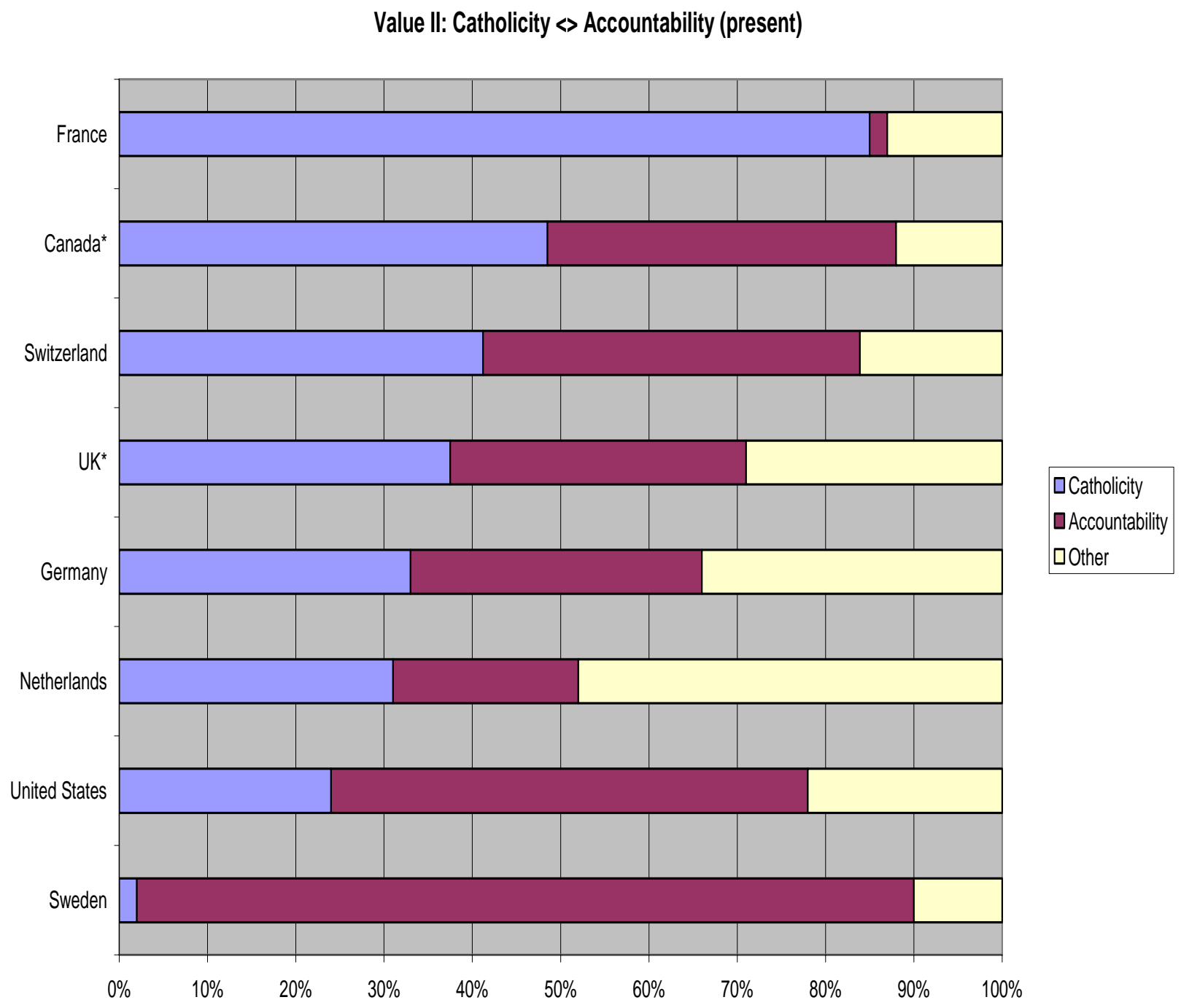

The above are very rough graphs derived from the above distinction between Catholicism, Lutheranism and Calvinism. By lack of a better measure, I counted members of the Anglican churches to 50\% (57\% of the British, but only 3\% of the Canadian population) on each side, because the contemporary Anglican Church's business ethics is a mix between Catholicism and Protestantism.

The charts embody the extreme sides of individualism and collectivism, and catholicism and accountability, respectively. The more extreme the country stands on the collectivist side, the more significant the influence of collectivist 
ethics on business behaviour, signalled by interference with market forces and underdeveloped stock markets. Similarly, the higher the level of catholicism, the fewer direct returns a shareholder may expect. However, it needs to be emphasized that a high level of indirect returns - something that has not been measured yet accurately - may counter the adverse effects of a less accountable management and controlling shareholders. ${ }^{231}$

\section{Morphing Values?}

The above considerations, with respect to path dependency, were subject to the condition that societies do not become indifferent with respect to cultural values that are based on religion. Besides religious indifference, which is not the same as atheism in this specific context, the ethical "path dependency" can also be overcome through certain societal values becoming more and more similar over time, due to access to similar sources of information, businesses, and politics. If values and norms morph over time, the functionality of certain rules should be expected to become similar, as well.

I personally believe that values among Western civilizations are converging, though this is yet based on speculation, rather than facts. As law is, to a certain extent, evidence of pre-eminent values, ${ }^{232}$ current corporate law reforms may support my hypothesis: British ${ }^{233}$ and American ${ }^{234}$ authors frequently argue in favour of expanding explicit devices of corporate control, which imply greater shareholder control over managers, while for e.g., the German legislature has expanded the pro-market rules over the last decade (at the expense of minority

${ }^{231}$ From an economic point of view, leisure time, social equality etc. may be understood as indirect returns of stakeholders in Continental jurisdictions.

${ }^{232}$ For the interaction between law and norms see Mitchell, supra note 53, at 235 et seq.

233 In fact, Eilis Ferran argued in The Role of the Shareholder in Internal Corporate Governance: Enabling Shareholders to make better informed decisions 4 EBOR 491 (2003), for strengthening explicit shareholder rights in UK and Europe.

${ }^{234}$ With Lucian A. Bebchuck playing the leading role in American academia, see for example The Case for Increasing Shareholder Power, 118:3 Harvard L.R. 833 (2005) and The Powerful Antitakeover Force of Staggered Boards: Theory, Evidence \& Policy (with John Coates IV \& Guhan Subramanian) 54 Stanford Law Review 887 (2002) and The Case Against Board Veto in Corporate Takeovers 69 University of Chicago Law Review 973 (2002). 
shareholders influence). ${ }^{235}$ Furthermore, the recent implementation of the European Directives on Market Abuse, Transparency, Prospectuses and Takeovers $^{236}$ brought French and German securities law closer to an Implicit System. However, at least, with respect to Canada and the United States, Michael Adams $^{237}$ does not share my view. By addressing the issue of morphing values, my paper would completely deviate from its topic, which is to show that there is, in fact, a correlation between ethics and corporate law. Thus, I will restrict myself and leave this far-reaching issue to sociologists and psychologists who are better trained and skilled to undertake such an endeavour than a corporate lawyer.

\section{F. Conclusion}

Aspects other than purely economic considerations can add to the understanding of present corporate governance systems. In particular, ethics grounded in certain strains of Christendom are likely to have influenced the specific development path that Anglo-American and Continental-European corporate governance systems took in times of industrialization. This development path formed the foundation of the corporate governance model that we see in Western countries today. This paper also determined which social norms are likely to prevail, and thus, which non-legal institutions complement the legal institutions in these countries today.

The results of this paper are apt to prompt reconsideration of those convergence theories that have refrained from acknowledging cultural influences as an important factor in answering the question which asks why, and to what extent, legal convergence is beneficial to societies. Further, while in times of

\footnotetext{
${ }^{235}$ See, e.g., Wolfgang Zöllner, Aktionär und Eigentum [Shareholder and Property], DER GESELLSCHAFTER 2004, 5; Noack \& Zetzsche, supra note 42.

236 Parliament and Council Directive 2003/6/EC on insider dealing and market manipulation (market abuse), 2003 O.J. (L 96) 16-23; Parliament and Council Directive 2004/109/EC on the harmonisation of transparency requirements in relation to information about issuers whose securities are admitted to trading on a regulated market, 2004 O.J. (L 390) 38-57; Parliament and Council Directive 2003/71/EC on the prospectus to be published when securities are offered to the public or admitted to trading, 2003 O.J. (L 345) 64-89; Parliament and Council Directive 2004/25/EC on takeover bids, 2004 O.J. (L 142) 12-23

${ }^{237}$ Supra note 209.
} 
economic growth people tend to veer toward atheism, people and policy-makers reconsider their cultural and religious identities in times of economic decline. Under this premise, morphing values and thus convergence of corporate governance rules - both from a legal and an efficiency perspective - seem more likely in times of economic growth, while path dependency is furthered when there is less to share. This ethical approach is consistent with economic explanations: in times where there is less wealth to go around, societies look for explanations to lock competitors out. Incumbents can easily mark intruders with the accusation of violating norms of the respective society. Partly, this accusation is correct because outsider management may look out for the loopholes of a laxer legal regime, as it does not personally feel obliged to adhere to the social norms in society. Normative restraints do not bind outsiders.

In light of these considerations, when adopting foreign legal regimes, legislators are strongly encouraged to review which non-legal influences explain, strengthen or balance the specific effects of the regime they seek to adopt. If they miss this aspect, they are likely to achieve different results than they intended with a potentially fatal impact on the countries' economy. 
$-74-$

Appendix 1: Religions in Major Jurisdictions of Europe and North America

Use of italics signals estimate by the author re Lutheran / Calvinist ; "Other" may include religions not specified in other columns.

\begin{tabular}{|c|c|c|c|c|c|c|c|c|c|}
\hline Year & Country & Catholics & Lutheran & Calvinist & Orthodox & Jewish & Muslims & Atheist & Other \\
\hline 2005 & Albania & $10,00 \%$ & \multirow{5}{*}{$\begin{array}{c}25,00 \% \\
4,00 \% \\
\end{array}$} & \multirow{5}{*}{$5,00 \%$} & \multirow{4}{*}{$\begin{array}{l}20,00 \% \\
60,00 \%\end{array}$} & & \multirow{4}{*}{$\begin{array}{c}70,00 \% \\
2,00 \%\end{array}$} & \multirow{5}{*}{$9,00 \%$} & \multirow{5}{*}{$\begin{array}{r}6,00 \% \\
32,00 \%\end{array}$} \\
\hline 2005 & Austria & $78,00 \%$ & & & & & & & \\
\hline 2000 & Belarus & $8,00 \%$ & & & & & & & \\
\hline 2005 & Belgium & $75,00 \%$ & & & & & & & \\
\hline 2005 & Bosnia Herz. & $15,00 \%$ & & & $31,00 \%$ & & $40,00 \%$ & & \\
\hline 2000 & Bulgaria & $1,00 \%$ & & \multirow{5}{*}{$40,00 \%$} & \multirow[t]{2}{*}{$84,00 \%$} & \multirow[t]{5}{*}{$1,00 \%$} & \multirow[t]{2}{*}{$13,00 \%$} & \multirow{5}{*}{$39,80 \%$} & \multirow{5}{*}{$\begin{array}{c}1,00 \% \\
\mathbf{1 2 , 0 0} \% \\
6,20 \% \\
13,40 \% \\
2,00 \% \\
\end{array}$} \\
\hline 2000 & Canada & $47,00 \%$ & $1,00 \%$ & & & & & & \\
\hline 2001 & Croatia & $87,80 \%$ & $0,30 \%$ & & \multirow{3}{*}{$\begin{array}{l}4,40 \% \\
3,00 \%\end{array}$} & & \multirow[t]{3}{*}{$1,30 \%$} & & \\
\hline 2005 & Czech Republic & $39,20 \%$ & $4,60 \%$ & & & & & & \\
\hline 2005 & Denmark & $2,00 \%$ & $95,00 \%$ & & & & & & \\
\hline 2005 & Finland & & $89,00 \%$ & \multirow{5}{*}{$2,00 \%$} & $1,00 \%$ & \multirow{5}{*}{$1,00 \%$} & \multirow{5}{*}{$\begin{array}{c}\mathbf{8 , 0 0} \% \\
30,00 \% \\
3,20 \% \\
1,30 \% \\
\end{array}$} & \multirow{5}{*}{$\begin{array}{r}9,00 \% \\
4,00 \% \\
28,30 \%\end{array}$} & \multirow{5}{*}{$\begin{array}{r}1,00 \% \\
3,00 \% \\
\mathbf{1 , 0 0 \%} \\
0,70 \% \\
\end{array}$} \\
\hline 2005 & France & $85,00 \%$ & & & \multirow{4}{*}{$\begin{array}{c}67,00 \% \\
\mathbf{1 , 5 0 \%} \\
98,00 \%\end{array}$} & & & & \\
\hline 2005 & FYROM & & \multirow{3}{*}{$33,00 \%$} & & & & & & \\
\hline 2005 & Germany & $33,00 \%$ & & & & & & & \\
\hline 2005 & Greece & & & & & & & & \\
\hline 2005 & Hungary & $67,50 \%$ & \multirow[t]{5}{*}{$5,00 \%$} & \multirow{4}{*}{$\begin{array}{c}20,00 \% \\
2,50 \%\end{array}$} & & & & & \multirow{5}{*}{$\begin{array}{c}7,50 \% \\
5,90 \% \\
2,69 \% \\
13,00 \% \\
5,00 \%\end{array}$} \\
\hline 1998 & Ireland & $91,60 \%$ & & & & & & & \\
\hline 2005 & Italy & $97,31 \%$ & & & & & & & \\
\hline 2000 & Luxembourg & $87,00 \%$ & & & & & & & \\
\hline 2005 & Mexico & $89,00 \%$ & & $6,00 \%$ & & & & & \\
\hline 1998 & Netherlands & $31,00 \%$ & \multirow{3}{*}{$89,00 \%$} & \multirow[t]{5}{*}{$21,00 \%$} & & & \multirow[t]{4}{*}{$4,40 \%$} & $40,00 \%$ & $3,60 \%$ \\
\hline 2000 & Norway & $1,00 \%$ & & & & & & & $10,00 \%$ \\
\hline 2005 & Poland & $75,00 \%$ & & & & & & $20,00 \%$ & $5,00 \%$ \\
\hline 1995 & Portugal & $94,00 \%$ & $6,00 \%$ & & & & & & \\
\hline 2002 & Romania & $5,60 \%$ & $6,80 \%$ & & $87,00 \%$ & & $0,40 \%$ & $0,20 \%$ & \\
\hline 2005 & Serbia Monten. & $4,00 \%$ & $1,00 \%$ & & $65,00 \%$ & & $19,00 \%$ & & $11,00 \%$ \\
\hline 2005 & Slovakia & $60,30 \%$ & $8,40 \%$ & & $4,10 \%$ & & & $9,70 \%$ & $17,50 \%$ \\
\hline 2005 & Slovenia & $70.8 \%$ & $1,00 \%$ & & & & $1,00 \%$ & $4,30 \%$ & $22,90 \%$ \\
\hline 2005 & Spain & $94,00 \%$ & & & & & & & $6,00 \%$ \\
\hline 2005 & Sweden & $2,00 \%$ & $87,00 \%$ & $1,00 \%$ & $1,00 \%$ & & $1,00 \%$ & & $8,00 \%$ \\
\hline 2000 & Switzerland & $41,20 \%$ & & $42,70 \%$ & $0,50 \%$ & $0,20 \%$ & $0,60 \%$ & $10,80 \%$ & $4,00 \%$ \\
\hline 2001 & UK & $9,00 \%$ & $5,00 \%$ & $57,00 \%$ & & $0,50 \%$ & $2,70 \%$ & $23,00 \%$ & $2,80 \%$ \\
\hline 2002 & United States & $24,00 \%$ & & $54,00 \%$ & & $1,00 \%$ & $1,00 \%$ & $10,00 \%$ & $10,00 \%$ \\
\hline
\end{tabular}

(Source CIA World Factbook March 2005; DK World Desk Reference 2000; WWW.wigipedia.de; adjustment by the author) 